\title{
Associations of house characteristics with indoor dampness and measured moisture: Results from three New Zealand House Condition Surveys in 2005, 2010 and 2015
}

\author{
Phoebe Taptiklis ${ }^{\text {a,b, }}$, Robyn Phipps ${ }^{c}$, Mark Jones ${ }^{\mathrm{d}}$, Jeroen Douwes ${ }^{\text {a }}$ \\ ${ }^{\text {a }}$ Research Centre for Hauora and Health, Massey University, Wellington, New Zealand \\ ${ }^{\mathrm{b}}$ Motu Economic and Public Policy Research, Wellington, New Zealand \\ ${ }^{\mathrm{c} S}$ Schools of Architecture and Design, Victoria University of Wellington, New Zealand \\ ${ }^{\mathrm{d}}$ BRANZ Ltd., Porirua, New Zealand
}

\section{A R T I C L E I N F O}

\section{Keywords:}

Building envelope

Indoor dampness

Measured moisture

Ventilation

Subfloor

House condition

\begin{abstract}
A B S T R A C T
Associations between house characteristics and inspector-assessed subjective indoor dampness (yes/no) and measured floor and ceiling joist timber moisture were measured, using the 2005, 2010 and 2015 New Zealand House Condition Surveys, involving 1572 timber-framed houses. We conducted logistic (dampness) and linear regression (moisture) for each survey separately and mutually adjusted for other house characteristics (ventilation, insulation, subfloor defects, building envelope condition (BEC) defects, tenure, number of occupants), climate zone (latitude), rainfall and outdoor temperature. The odds of subjective damp increased with: more BEC defects (p for trend $<0.001$ ), with adjusted odds ratios (aORs) of 3.9-9.6 (p $<0.001$ ) across surveys for houses with 4 or 5 (of 5 ) defects, compared with houses with $\leq 1$ defect; more subfloor defects ( $\mathrm{p}$ for trend $<0.01$ for 2010 and 2015 surveys); less ventilation (p for trend $<0.05$ for 2010 and 2015 surveys); less insulation (p for trend $\leq 0.05$ for 2010); and increased occupancy (aORs 1.2-2.3, for $\geq 5$ occupants compared to 1-2, not significant). Dampness was more common in rental houses (aORs 1.6 to $2.2, \mathrm{p}<0.05$ in 2015). Floor joist moisture content was higher in houses with more subfloor $(1.2 \%-1.9 \%$ increase per defect, $\mathrm{p}$ for trend $\leq 0.01)$ and BEC defects (1.5\%-1.8\% for houses with 4-5 defects, $\mathrm{p}<0.001$ for 2005 and 2015 surveys). In conclusion, subfloor and building envelope defects were associated with both inspector-assessed dampness and objectively measured moisture in floor joists. Less insulation, ventilation and higher occupancy were associated with increased subjective dampness but not with measured moisture.
\end{abstract}

\section{Introduction}

Consistent associations between indoor dampness and respiratory ill health have been reported [1,2], with mould exposure hypothesised to play an important role, although the evidence for this has been equivocal [3-6]. While much attention has gone into improving quantitative measures of indoor mould [7,8], the strongest associations with ill health are generally observed with qualitative observations of dampness and mouldy odour, and semi-quantitative observations of mould (as measured by extent or size of mould contaminating on wall and other surfaces) $[1,9,10]$.

House and household characteristics have been associated with subjective dampness indicators in several studies, including higher occupancy [11-14], tenancy vs home ownership [15-17], no or poor insulation [18,19], lack of (mechanical) ventilation [15,16,20], older houses [11,16,20-22], and poor repairs and maintenance [16,23,24]. Some of these characteristics have also been associated with higher indoor relative humidity or other objective measures of dampness, including higher occupancy $[25,27,28]$, lack of insulation [19,27], lack of efficient and effective heating [25,26,27,29] and less ventilation [30]. However, results have not always been consistent, potentially because currently there are no standardised and widely accepted indicators of, or validated methods for, measuring indoor dampness. Similarly, reported associations between home characteristics and indoor mould have been equivocal $[31,32]$, likely due to different approaches used to measure mould. Also, most studies have focused on only a small number of house characteristics, resulting in significant knowledge gaps. In particular, although improved house maintenance is frequently referred to in

\footnotetext{
* Corresponding author. Research Centre for Hauora and Health, Massey University, Wellington, New Zealand.

E-mail address: phoebe.taptiklis@motu.org.nz (P. Taptiklis).
} 
advice for occupants to reduce indoor dampness [33], and epidemiological studies have identified "poor repair" and "infrequent maintenance" as risk factors for indoor dampness and mould [16,23], it remains unclear which specific aspects of maintenance are most critical. Improved understanding of the specific house and household characteristics that contribute to indoor dampness will facilitate the development of more effective interventions.

We have previously reported associations between house characteristics and visible mould and musty odour using data from three iterations of the New Zealand House Condition Survey, conducted in 2005 ( $n=565), 2010(n=491)$ and $2015(n=560)$ [24]. These three surveys collected detailed data on the physical characteristics of these houses as well as some household characteristics, and showed that poorer ventilation, insulation and condition of the building envelope were independently associated with increased visible mould and musty odour (both inspector assessed), after adjustment for climate and other household characteristics including tenure and number of occupants [24]. The aims of the current study were to assess associations with outcomes of inspector-rated subjective (feeling of) indoor dampness and moisture measurements (moisture content) taken from ceiling and floor joist timbers using data from the same three surveys, with the overall goal of improving understanding of the determinants of indoor dampness, thus contributing to improved interventions to reduce indoor dampness.

\section{Methods}

The New Zealand House Condition Survey (HCS) is conducted by the Building Research Association of New Zealand (BRANZ) and has been undertaken approximately every five years since 1994 [34]. The study reported here, used data collected from the three most recent surveys i.e. 2005, 2010 and 2015. The sampling methodology and assessor training are described in detail elsewhere [35-37] respectively. Briefly, the three surveys were predominantly restricted to single family, timber-framed dwellings. Apartments were not included, as they were an uncommon housing typology in New Zealand during the period of the three HCS. While using almost identical assessment protocols, there were some differences between the three HCSs: in 2005, the sample was limited to only owner-occupied houses in the three largest New Zealand cities and outlying regions (Auckland and Wellington in the North Island, and Christchurch in the South Island); and for the 2010 and 2015 HCSs, rental houses and houses located in other cities and rural towns were included, and a sampling structure was developed to capture a more representative sample of dwellings. The sampling structure for the 2010 and 2015 surveys involved dividing the country into 13 strata, 11 of which corresponded to urban areas, with the remaining two strata involving the rest of the North Island, and the rest of the South Island. Cluster-sampling was used within strata based on census mesh-blocks (smallest statistical area unit). Also, from 2010 onwards, additional training for the home inspectors was provided to increase the consistency of damp and condition assessments. This involved a day of theoretical training, including how to conduct moisture assessments, followed by supervised inspections. Weathertightness, a term used in New Zealand to describe a building's ability to prevent water from penetrating the building envelope [38] was not a specific category assessed by the surveys.

\subsection{Climatic conditions and housing stock in New Zealand}

New Zealand has a temperate maritime climate, characterised by relatively high year-round humidity and a relatively small annual range $\left(10{ }^{\circ} \mathrm{C}\right)$ of mean daily temperature. Its housing stock consists predominantly of timber construction. The sample of houses included in the three housing condition surveys described in this paper is generally reflective of the range of residential construction styles found in New Zealand, although since 2015 a consistently higher proportion of multi- unit, multi-level residential buildings have been constructed, and these are not well represented in the samples used here, which are predominantly stand-alone, single-family dwellings.

\subsection{House characteristics}

The surveys included $>1500$ individual components, including the presence of insulation, heaters and ventilation systems, site details such as location, slope of site, and exposure to noise, air pollution and sun. Other information collected included number of occupants, year of construction and date of survey. For the current study, 77 variables were selected as plausibly associated with indoor or framing moisture (Table 2). Inspection of wall cavities to assess the presence of insulation were conducted in the 2005 survey, but this was discontinued in later surveys due to practicality and health and safety concerns. In these cases, wall insulation was identified based on the house age (in relation to changes in building code insulation requirements) and conversations with the occupants.

Information on ceiling insulation was available in two dimensions $i$. e. proportion of the ceiling (of the whole house) covered, and thickness of the insulation. These variables were analysed separately in univariate analysis, which showed that an index combing the two dimensions improved the explained variance (in univariate analysis) compared to either variable separately. Therefore, in multivariate analysis ceiling insulation was analysed using an index describing both thickness and coverage (least $/ \mathrm{mid} / \mathrm{most}$ ). For the ceiling insulation index we allocated one point to insulation that was $<50 \mathrm{~mm}$ thick, 2 points for insulation thickness of 50-100 mm and 3 points if thickness was $>100 \mathrm{~mm}$. For the proportion of the ceiling covered we allocated 1 point for $0-25 \%$ coverage, 2 points for $30-75 \%$ coverage, and 3 points for $80-100 \%$ coverage. The values for these variables were subsequently summed and then reduced to a 3-point scale using the following cut-points: $1-3=$ "Least"; 4-5 = "Mid"; and 6 = "Most". The cut-points were chosen to balance the need to reflect real differences in insulation between subgroups, whilst ensuring sufficient observations in each sub-group to conduct multivariate regression analyses with adequate power.

Along with detailed recording of material types for most of the building components, condition ratings on a 5-point scale (Excellent, Good, Moderate, Poor, Serious) were used for major components i.e., windows, doors, roof, gutters, subfloor ventilation, exterior paint condition, etc. These rating values were based on inspectors' assessments of the urgency and level of any potential repair required to bring the component to "as new" condition, with "as new" defined as "no signs of damage/wear and tear, and no maintenance requirements at present. For this study, rating variables were used as a binary measure: excellent/ good versus moderate/poor/serious. The primary reason for grouping the results this way was to ensure sufficient frequencies in each (sub-) group.

\subsection{Subjective indoor dampness}

Dampness was assessed (subjectively) by inspectors after completing the indoor inspection using the following categories: dry, some damp, damp throughout [34]. These categories were based on a subjective "feeling" of dampness. For the analyses described in this paper, "some damp" and "damp throughout" were combined and used in a binary dry/damp variable. The 2010 survey included a high number of missing values for the dampness variable (29\%), particularly for the earliest period of data collection. Comparing houses with and without missing data for dampness showed that key home characteristics (i.e. house age, presence of insulation, presence of mechanical ventilation, number or type of heaters and visible mould) did not appreciably differ between both groups (data not shown), suggesting that missing data is unlikely to have resulted in a systematic bias of our sample. Results reported in the tables are based on houses with no missing data for the main outcome variables (i.e. subjective dampness and measured moisture in ceiling 
Table 1

Sample characteristics.

\begin{tabular}{|c|c|c|c|}
\hline & $\begin{array}{l}2005(565 \\
\text { houses) }\end{array}$ & $\begin{array}{l}2010(491 \\
\text { houses) }\end{array}$ & $\begin{array}{l}2015(560 \\
\text { houses) }\end{array}$ \\
\hline & Mean \pm SD & Mean \pm SD & Mean \pm SD \\
\hline Roof joist moisture (MC) & $10.8 \pm 1.7$ & $11.9 \pm 3.3$ & $10.6 \pm 5.1$ \\
\hline Floor joist moisture (MC) & $19.2 \pm 4.4$ & $16.5 \pm 2.7$ & $16.6 \pm 3.4$ \\
\hline $\begin{array}{l}\text { Assessed for moisture/ } \\
\text { damp }\end{array}$ & $N(\%)$ & $N(\%)$ & $N(\%)$ \\
\hline Floor joist moisture & $326(58)$ & $286(58)$ & $323(58)$ \\
\hline Roof joist moisture & $482(85)$ & $376(77)$ & $422(75)$ \\
\hline Subjective dampness & $565(100)$ & $348(71)$ & $539(96)$ \\
\hline \multicolumn{4}{|l|}{ Subjective damp } \\
\hline Of assessed: Dry & $502(88)$ & $257(74)$ & $459(85)$ \\
\hline A little damp & $54(10)$ & $50(14)$ & $53(10)$ \\
\hline Damp throughout & $9(2)$ & 41 (12) & $27(5)$ \\
\hline \multicolumn{4}{|l|}{ Survey season } \\
\hline $\begin{array}{l}\text { Summer } \\
\text { (December-February) }\end{array}$ & $540(96)$ & $50(10)$ & $172(31)$ \\
\hline Autumn (March-May) & $10(2)$ & - & 149 (27) \\
\hline Winter (June-August) & - & $56(12)$ & $1(0)$ \\
\hline $\begin{array}{l}\text { Spring } \\
\quad \text { (September-November) }\end{array}$ & $15(3)$ & $383(78)$ & $238(43)$ \\
\hline \multicolumn{4}{|l|}{ 30-day rain } \\
\hline $0-50 \mathrm{~mm}$ & $302(53)$ & $206(42)$ & $308(56)$ \\
\hline $51-100 \mathrm{~mm}$ & $212(38)$ & $104(21)$ & $199(36)$ \\
\hline $101-150 \mathrm{~mm}$ & $44(8)$ & $70(14)$ & $41(7)$ \\
\hline $151 \mathrm{~mm}$ or more & $7(1)$ & $107(22)$ & $6(1)$ \\
\hline \multicolumn{4}{|l|}{ 30-day temp (average) } \\
\hline$<15^{\circ} \mathrm{C}$ & 0 & $177(36)$ & $48(9)$ \\
\hline $15.1-20^{\circ} \mathrm{C}$ & $183(32)$ & $260(53)$ & $233(42)$ \\
\hline $20.1-25^{\circ} \mathrm{C}$ & $315(56)$ & $49(10)$ & $229(41)$ \\
\hline$>25{ }^{\circ} \mathrm{C}$ & $67(12)$ & $1(0.2)$ & $47(8)$ \\
\hline \multicolumn{4}{|l|}{ Climate zone } \\
\hline North & $304(54)$ & $161(33)$ & $183(33)$ \\
\hline Mid & $111(20)$ & $227(46)$ & $159(28)$ \\
\hline South & $150(26)$ & $101(21)$ & 218 (39) \\
\hline \multicolumn{4}{|l|}{ Age category } \\
\hline Pre 1930 & 87 (15) & $58(13)$ & $62(11)$ \\
\hline 1930-1979 & $307(55)$ & $242(52)$ & $294(53)$ \\
\hline 1980 and older & $167(30)$ & $163(35)$ & $204(36)$ \\
\hline \multicolumn{4}{|l|}{$\begin{array}{l}\text { Overall Condition Rating } \\
\text { (OCR) }\end{array}$} \\
\hline Well maintained & $280(50)$ & $125(25)$ & $243(44)$ \\
\hline Reasonably maintained & $195(35)$ & $127(26)$ & 220 (39) \\
\hline Poorly maintained & $85(15)$ & $112(23)$ & $96(17)$ \\
\hline Missing & $5(1)$ & $127(26)$ & \\
\hline \multicolumn{4}{|l|}{ Tenure } \\
\hline Rented & - & $108(22)$ & 149 (27) \\
\hline Owner occupied & $565(100)$ & $383(78)$ & $411(73)$ \\
\hline \multicolumn{4}{|l|}{ Occupants } \\
\hline 1 to 2 & $273(48)$ & $277(56)$ & $336(60)$ \\
\hline 3 to 4 & $213(38)$ & $167(34)$ & $175(31)$ \\
\hline 5 or more & $63(11)$ & $47(10)$ & $49(9)$ \\
\hline Missing & $16(3)$ & & \\
\hline \multicolumn{4}{|l|}{ Bedrooms } \\
\hline 1 to 2 & $35(6)$ & $74(15)$ & 104 (19) \\
\hline 3 to 4 & 489 (87) & $392(80)$ & $422(75)$ \\
\hline 5 or more & $41(7)$ & $23(5)$ & $32(5.5)$ \\
\hline Missing & & & $2(0.5)$ \\
\hline \multicolumn{4}{|l|}{ Foundation Type } \\
\hline Piles & $321(57)$ & $314(64)$ & $339(60)$ \\
\hline Concrete slab & $148(26)$ & $137(28)$ & 207 (37) \\
\hline Mixed foundations & $96(17)$ & $40(8)$ & $14(3)$ \\
\hline \multicolumn{4}{|l|}{ Cladding Type } \\
\hline Timber weatherboard & $186(33)$ & $97(20)$ & $128(23)$ \\
\hline Fibre cement & $55(10)$ & $43(9)$ & $66(12)$ \\
\hline Brick & $86(15)$ & $61(12)$ & $110(20)$ \\
\hline Mixed/other & $238(42)$ & 290 (59) & $256(46)$ \\
\hline \multicolumn{4}{|l|}{ Roof Type } \\
\hline Metal roof & $372(66)$ & $287(58)$ & $409(73)$ \\
\hline Concrete/clay tiles & $183(32)$ & $201(41)$ & $121(22)$ \\
\hline Other & $10(2)$ & $3(1)$ & $30(5)$ \\
\hline
\end{tabular}

Table 2

Tested variables.

\begin{tabular}{|c|c|c|c|c|c|}
\hline Variables tested & 2005 & 2010 & 2015 & $\begin{array}{l}\text { Categorisation for } \\
\text { univariate and } \\
\text { multivariate } \\
\text { analyses }\end{array}$ & $\begin{array}{l}\text { Aggregation } \\
\text { for domains }\end{array}$ \\
\hline $\begin{array}{l}\text { Total rainfall } \\
\text { over previous } \\
30 \text { days }\end{array}$ & $\checkmark$ & $\checkmark$ & $\checkmark$ & Continuous & continuous \\
\hline $\begin{array}{l}\text { Average daily } \\
\text { high } \\
\text { temperature } \\
\text { over previous } \\
30 \text { days }\end{array}$ & $\checkmark$ & $\checkmark$ & $\checkmark$ & Continuous & Continuous \\
\hline $\begin{array}{l}\text { Range hood } \\
\quad \text { (extract over } \\
\text { cooker) }\end{array}$ & $\checkmark$ & $\checkmark$ & $\checkmark$ & $\begin{array}{l}\text { Included in count } \\
\text { of kitchen extract } \\
\text { ventilation (max }\end{array}$ & $\begin{array}{l}\text { Ventilation } \\
\text { domain ( } 1 \text { of } \\
\text { 3) }\end{array}$ \\
\hline $\begin{array}{l}\text { Other } \\
\text { mechanical } \\
\text { kitchen } \\
\text { ventilation }\end{array}$ & $\checkmark$ & $\checkmark$ & - & $\begin{array}{l}\text { of one) } \\
\text { Yes } \\
\text { No }\end{array}$ & $\begin{array}{l}\text { No }=0 \\
\text { Yes }=1\end{array}$ \\
\hline $\begin{array}{l}\text { Indoor clothes } \\
\text { dryer } \\
\text { ventilation } \\
\text { ducting } \\
\text { present }\end{array}$ & $\checkmark$ & $\checkmark$ & $\checkmark$ & $\begin{array}{l}\text { No dryer present } \\
\text { Dryer not } \\
\text { ventilated } \\
\text { Ventilated to } \\
\text { outside Ventilated } \\
\text { to roof space }\end{array}$ & $\begin{array}{l}\text { Ventilation } \\
\text { domain ( } 1 \text { of } \\
\text { 3) } \\
\text { If dryer } \\
\text { present and } \\
\text { ducted to the } \\
\text { outside = } 1 \\
\text { All other } \\
\text { options }=0\end{array}$ \\
\hline $\begin{array}{l}\text { Bathroom } \\
\text { extract } \\
\text { ventilation } \\
\text { fan }\end{array}$ & $\checkmark$ & $\checkmark$ & $\checkmark$ & $\begin{array}{l}\text { No } \\
\text { Yes }\end{array}$ & $\begin{array}{l}\text { Ventilation } \\
\text { domain ( } 1 \text { of } \\
3 \text { ) } \\
\text { No }=0 \\
\text { Yes }=1\end{array}$ \\
\hline $\begin{array}{l}\text { Ceiling space } \\
\text { insulation } \% \\
\text { coverage } \\
0-25 \% \\
30-75 \% \\
\text { Over } 75 \%\end{array}$ & $\checkmark$ & $\checkmark$ & $\checkmark$ & $\begin{array}{l}\text { Combined } \\
\text { insulation index } \\
\text { Least } \\
\text { Mid } \\
\text { Most }\end{array}$ & $\begin{array}{l}\text { Insulation } \\
\text { domain (1 of } \\
3 \text { reverse } \\
\text { coded) } \\
\text { Most }=0 \\
\text { Mid/Least = } 1\end{array}$ \\
\hline $\begin{array}{l}\text { Ceiling space } \\
\text { insulation } \\
\text { thickness } \\
\text { Less than } 50 \\
\mathrm{~mm} \\
50-100 \mathrm{~mm} \\
\text { Over } 100 \mathrm{~mm}\end{array}$ & $\checkmark$ & $\checkmark$ & $\checkmark$ & & \\
\hline Wall Insulation & $\checkmark$ & $\checkmark$ & $\checkmark$ & $\begin{array}{l}\text { No } \\
\text { Yes }\end{array}$ & $\begin{array}{l}\text { Insulation } \\
\text { domain ( } 1 \text { of } \\
3 \text { reverse } \\
\text { coded) } \\
\text { No }=1 \\
\text { Yes }=0\end{array}$ \\
\hline $\begin{array}{l}\text { Underfloor } \\
\text { insulation } \\
(>50 \% \\
\text { coverage })\end{array}$ & $\checkmark$ & $\checkmark$ & $\checkmark$ & $\begin{array}{l}\text { Yes } \\
\text { No }\end{array}$ & $\begin{array}{l}\text { Insulation } \\
\text { domain ( } 1 \text { of } \\
3 \text { reverse } \\
\text { coded) } \\
\text { No }=1 \\
\text { Yes }=0\end{array}$ \\
\hline $\begin{array}{l}\text { Ground cover } \\
\text { under house } \\
(>50 \% \\
\text { coverage })\end{array}$ & $\checkmark$ & $\checkmark$ & $\checkmark$ & $\begin{array}{l}\text { No } \\
\text { Yes }\end{array}$ & $\begin{array}{l}\begin{array}{l}\text { Subfloor } \\
\text { defect } \\
\text { domain ( } 1 \text { of } \\
\text { 3) } \\
\text { If house has a } \\
\text { suspended } \\
\text { floor } \\
\text { Yes }=0 \\
\text { No }=1\end{array}\end{array}$ \\
\hline $\begin{array}{l}\text { Plumbing } \\
\text { leaking under } \\
\text { house }\end{array}$ & $\checkmark$ & $\checkmark$ & $\checkmark$ & $\begin{array}{l}\text { (Combined with } \\
\text { Ponding under } \\
\text { house; } \max =1 \text { ) } \\
\text { No }=0 \\
\text { Yes }=1\end{array}$ & $\begin{array}{l}\text { Subfloor } \\
\text { domain (1 of } \\
\text { 3) } \\
\text { If house has a } \\
\text { suspended }\end{array}$ \\
\hline $\begin{array}{c}\text { Water ponding } \\
\text { under house }\end{array}$ & $\checkmark$ & $\checkmark$ & $\checkmark$ & $\begin{array}{l}\text { (Combined with } \\
\text { Plumbing leaks } \\
\text { under house; max }\end{array}$ & $\begin{array}{l}\text { floor } \\
\text { Plumbing } \\
\text { leaks or }\end{array}$ \\
\hline
\end{tabular}


Table 2 (continued)

\begin{tabular}{|c|c|c|c|c|c|}
\hline Variables tested & 2005 & 2010 & 2015 & $\begin{array}{l}\text { Categorisation for } \\
\text { univariate and } \\
\text { multivariate } \\
\text { analyses }\end{array}$ & $\begin{array}{l}\text { Aggregation } \\
\text { for domains }\end{array}$ \\
\hline $\begin{array}{l}\text { Subfloor } \\
\text { ventilation } \\
\text { above/below } \\
\text { requirements }\end{array}$ & $\checkmark$ & $\checkmark$ & $\checkmark$ & $\begin{array}{l}=1) \\
\text { No }=0 \\
\text { Yes }=1 \\
\text { Yes } \\
\text { No }\end{array}$ & $\begin{array}{l}\text { ponding under } \\
\text { house }=1 \\
\text { All other } \\
\text { options }=0 \\
\text { Subfloor } \\
\text { domain ( } 1 \text { of } \\
\text { 3) } \\
\text { If house has a } \\
\text { suspended } \\
\text { floor } \\
\text { No }=1 \\
\text { All other } \\
\text { options }=0\end{array}$ \\
\hline $\begin{array}{l}\text { Wall cladding } \\
\text { condition }\end{array}$ & $\checkmark$ & $\checkmark$ & $\checkmark$ & $\begin{array}{l}\text { Excellent/Good = } \\
0 \\
\text { Moderate/poor/ } \\
\text { serious }=1\end{array}$ & $\begin{array}{l}\text { BEC domain } \\
(1 \text { of } 5) \\
\text { No }=0 \\
\text { Yes }=1\end{array}$ \\
\hline $\begin{array}{l}\text { Spouting and } \\
\text { guttering } \\
\text { condition } \\
\text { rating }\end{array}$ & $\checkmark$ & $\checkmark$ & $\checkmark$ & $\begin{array}{l}\text { Excellent/Good = } \\
0 \\
\text { Moderate/poor/ } \\
\text { serious }=1\end{array}$ & $\begin{array}{l}\text { BEC domain } \\
\text { (1 of 5) } \\
\text { Excellent/ } \\
\text { Good }=0 \\
\text { Moderate/ } \\
\text { poor/serious } \\
=1\end{array}$ \\
\hline $\begin{array}{l}\text { Wall cladding } \\
\text { paint } \\
\text { deterioration }\end{array}$ & $\checkmark$ & $\checkmark$ & $\checkmark$ & $\begin{array}{l}\text { No } \\
\text { Yes }\end{array}$ & $\begin{array}{l}\text { BEC domain } \\
(1 \text { of } 5) \\
\text { No }=0 \\
\text { Yes }=1\end{array}$ \\
\hline $\begin{array}{l}\text { Windows } \\
\text { condition } \\
\text { rating }\end{array}$ & $\checkmark$ & $\checkmark$ & $\checkmark$ & $\begin{array}{l}\text { Excellent/Good = } \\
0 \\
\text { Moderate/poor/ } \\
\text { serious }=1\end{array}$ & $\begin{array}{l}\text { BEC domain } \\
\text { (1 of 5) } \\
\text { Excellent/ } \\
\text { Good }=0 \\
\text { Moderate/ } \\
\text { poor/serious } \\
=1\end{array}$ \\
\hline $\begin{array}{l}\text { Roof condition } \\
\text { rating }\end{array}$ & $\checkmark$ & $\checkmark$ & $\checkmark$ & $\begin{array}{l}\text { Excellent/Good = } \\
0 \\
\text { Moderate/poor/ } \\
\text { serious }=1\end{array}$ & $\begin{array}{l}\text { BEC domain } \\
\text { (1 of 5) } \\
\text { Excellent/ } \\
\text { Good }=0 \\
\text { Moderate/ } \\
\text { poor/serious } \\
=1\end{array}$ \\
\hline Climate zone & $\checkmark$ & $\checkmark$ & $\checkmark$ & $\begin{array}{l}\text { North } \\
\text { Mid } \\
\text { South }\end{array}$ & $\begin{array}{l}\text { North } \\
\text { Mid } \\
\text { South }\end{array}$ \\
\hline $\begin{array}{l}\text { Owner } \\
\text { occupied/ } \\
\text { rental }\end{array}$ & - & $\checkmark$ & $\checkmark$ & $\begin{array}{l}\text { Owner } \\
\text { Tenant }\end{array}$ & $\begin{array}{l}\text { Owner } \\
\text { Tenant }\end{array}$ \\
\hline $\begin{array}{l}\text { Number of } \\
\text { occupants }\end{array}$ & $\checkmark$ & $\checkmark$ & $\checkmark$ & $\begin{array}{l}1-2 \\
3-4 \\
5 \text { or more }\end{array}$ & $\begin{array}{l}1-2 \\
3-4 \\
5 \text { or more }\end{array}$ \\
\hline $\begin{array}{l}\text { General } \\
\text { maintenance } \\
\text { assessment }\end{array}$ & $\checkmark$ & $\checkmark$ & $\checkmark$ & $\begin{array}{l}\text { Excellent/Good }= \\
0 \\
\text { Moderate }=2 \\
\text { Poor } / \text { serious }=3\end{array}$ & $\begin{array}{l}\text { Excellent/ } \\
\text { Good }=0 \\
\text { Moderate }=2 \\
\text { Poor/serious } \\
=3\end{array}$ \\
\hline Surveyor & $\checkmark$ & $\checkmark$ & $\checkmark$ & ID no. & ID no. \\
\hline Age of house & $\checkmark$ & $\checkmark$ & $\checkmark$ & $\begin{array}{l}\text { Pre } 1930 \\
1930-1979 \\
\text { Post } 1980 \\
\text { Missing/mixed }\end{array}$ & - \\
\hline $\begin{array}{l}\text { Date of } \\
\text { assessment } \\
\text { (aggregated } \\
\text { by month and } \\
\text { season) }\end{array}$ & $\checkmark$ & $\checkmark$ & $\checkmark$ & $\begin{array}{l}\text { Dec-Feb } \\
\text { Mar-May } \\
\text { June-Aug } \\
\text { Sep-Nov }\end{array}$ & - \\
\hline No. of storeys & $\checkmark$ & $\checkmark$ & $\checkmark$ & - & - \\
\hline No. bedrooms & $\checkmark$ & $\checkmark$ & $\checkmark$ & - & - \\
\hline Floor area & $\checkmark$ & $\checkmark$ & - & - & - \\
\hline $\begin{array}{l}\text { Close to busy } \\
\text { road } \\
\text { (combined } \\
\text { with Noise) }\end{array}$ & $\checkmark$ & $\checkmark$ & $\checkmark$ & $\begin{array}{l}\text { (max of } 1 \text { ) } \\
\text { Not close to busy } \\
\text { road }=0 \\
\text { Close to busy road }\end{array}$ & - \\
\hline
\end{tabular}

Table 2 (continued)

\begin{tabular}{|c|c|c|c|c|c|}
\hline Variables tested & 2005 & 2010 & 2015 & $\begin{array}{l}\text { Categorisation for } \\
\text { univariate and } \\
\text { multivariate } \\
\text { analyses }\end{array}$ & $\begin{array}{l}\text { Aggregation } \\
\text { for domains }\end{array}$ \\
\hline Noise & $\checkmark$ & $\checkmark$ & $\checkmark$ & $\begin{array}{l}=1 \\
\text { Always/mostly } \\
\text { quiet }=0 \\
\text { Moderate/loud } \\
\text { noise }=1\end{array}$ & \\
\hline House in shade & $\checkmark$ & $\checkmark$ & $\checkmark$ & $\begin{array}{l}\text { No/some shade } \\
\text { Shady most/all } \\
\text { day }\end{array}$ & - \\
\hline $\begin{array}{l}\text { House } \\
\text { sheltered/ } \\
\text { exposed }\end{array}$ & - & $\checkmark$ & $\checkmark$ & - & - \\
\hline $\begin{array}{l}\text { House built on } \\
\text { slope }\end{array}$ & $\checkmark$ & $\checkmark$ & $\checkmark$ & - & - \\
\hline $\begin{array}{l}\text { Type and } \\
\text { number of } \\
\text { heaters }\end{array}$ & $\checkmark$ & $\checkmark$ & $\checkmark$ & $\begin{array}{l}\text { Number of gas } \\
\text { appliances } \\
\text { (heaters, fixed } \\
\text { portable and } \\
\text { oven/stove) } \\
\text { Number of electric } \\
\text { appliances } \\
\text { (heaters, fixed } \\
\text { portable and } \\
\text { oven/stove) } \\
\text { Number of } \\
\text { enclosed fire } \\
\text { places/pellet } \\
\text { burners } \\
\text { Number of open } \\
\text { fire places }\end{array}$ & - \\
\hline
\end{tabular}

$\begin{array}{lllll}\begin{array}{l}\text { Heating } \\ \text { behaviour }\end{array} & - & - & \checkmark & - \\ \text { Air conditioner } & \checkmark & \checkmark & \checkmark & \begin{array}{l}\text { Included in count } \\ \text { of electric heaters } \\ (=1)\end{array} \\ \text { Dehumidifier } & \checkmark & \checkmark & \checkmark & -\end{array}$

$\begin{array}{lllll}\text { Dehumidifier } & \checkmark & \checkmark & \checkmark & - \\ \text { Heat recovery } & \checkmark & \checkmark & \checkmark & -\end{array}$

air treatment

Cooker electric/

gas

Floor coverings

living room/

bedrooms

Signs of leaking $\quad \checkmark \quad \checkmark \quad \checkmark \quad$ Combined with

indoors

roof leaks and

signs of leaking

internal gutters

No

Yes

Foundation

type

(concrete

slab, piles,

perimeter

wall)

Basement

present

Basement signs

of leaks

Cladding

deterioration

near ground

Subfloor vents

covered by

vegetation

Subfloor

ventilation

condition

rating

Wall cladding

minor cracks
Included in count of gas/electric heaters $(=1)$

-
Excellent/Good $=$ 0

Moderate/poor/ serious $=1$ 
Table 2 (continued)

\begin{tabular}{|c|c|c|c|c|c|}
\hline Variables tested & 2005 & 2010 & 2015 & $\begin{array}{l}\text { Categorisation for } \\
\text { univariate and } \\
\text { multivariate } \\
\text { analyses }\end{array}$ & $\begin{array}{l}\text { Aggregation } \\
\text { for domains }\end{array}$ \\
\hline \multicolumn{6}{|l|}{$\begin{array}{l}\text { Wall cladding } \\
\text { holes/major } \\
\text { cracks }\end{array}$} \\
\hline $\begin{array}{l}\text { Ext. doors } \\
\text { condition } \\
\text { rating }\end{array}$ & $\checkmark$ & $\checkmark$ & $\checkmark$ & - & - \\
\hline Roof material & $\checkmark$ & $\checkmark$ & $\checkmark$ & $\begin{array}{l}\text { Metal } \\
\text { Concrete/clay tile } \\
\text { Missing/mixed/ } \\
\text { other }\end{array}$ & - \\
\hline Roof slope & - & $\checkmark$ & $\checkmark$ & - & - \\
\hline Roof leaks & $\checkmark$ & $\checkmark$ & $\checkmark$ & $\begin{array}{l}\text { Combined with } \\
\text { Signs of leaking } \\
\text { indoors }(\max =1) \\
\text { No } \\
\text { Yes }\end{array}$ & - \\
\hline $\begin{array}{l}\text { No. of spouting } \\
\text { defects }\end{array}$ & $\checkmark$ & $\checkmark$ & $\checkmark$ & - & - \\
\hline $\begin{array}{l}\text { Internal gutters } \\
\text { leaking }\end{array}$ & $\checkmark$ & $\checkmark$ & $\checkmark$ & $\begin{array}{l}\text { Combined with } \\
\text { Signs of leaking } \\
\text { indoors }(\max =1) \\
\text { No } \\
\text { Yes }\end{array}$ & - \\
\hline $\begin{array}{l}\text { Window } \\
\text { material }\end{array}$ & $\checkmark$ & $\checkmark$ & $\checkmark$ & $\begin{array}{l}\text { Timber } \\
\text { Metal } \\
\text { Missing/mixed/ } \\
\text { other }\end{array}$ & - \\
\hline $\begin{array}{l}\text { Windows } \\
\text { double glazed }\end{array}$ & $\checkmark$ & $\checkmark$ & $\checkmark$ & $\begin{array}{l}50 \% \text { or less }=0 \\
>50 \%=1\end{array}$ & - \\
\hline $\begin{array}{l}\text { Window } \\
\text { flashing } \\
\text { deterioration }\end{array}$ & $\checkmark$ & $\checkmark$ & $\checkmark$ & $\begin{array}{l}\text { Combined with } \\
\text { window flashings } \\
\text { missing }(\max =1) \\
\text { No }=0 \\
\text { Yes }=1\end{array}$ & - \\
\hline $\begin{array}{l}\text { Window } \\
\text { flashings } \\
\text { missing }\end{array}$ & $\checkmark$ & $\checkmark$ & $\checkmark$ & $\begin{array}{l}\text { Combined with } \\
\text { window flashing } \\
\text { deterioration } \\
(\max =1) \\
\text { No }=0 \\
\text { Yes }=1\end{array}$ & - \\
\hline $\begin{array}{l}\text { Windows joint } \\
\text { cracks }\end{array}$ & $\checkmark$ & $\checkmark$ & $\checkmark$ & - & - \\
\hline $\begin{array}{l}\text { Windows } \\
\text { missing/ } \\
\text { cracked putty }\end{array}$ & $\checkmark$ & $\checkmark$ & $\checkmark$ & - & - \\
\hline $\begin{array}{l}\text { Windows } \\
\text { missing/ } \\
\text { shrunk rubber } \\
\text { seals }\end{array}$ & $\checkmark$ & $\checkmark$ & $\checkmark$ & - & - \\
\hline $\begin{array}{r}\text { Windows } \\
\text { leaking }\end{array}$ & $\checkmark$ & $\checkmark$ & $\checkmark$ & - & - \\
\hline $\begin{array}{l}\text { Windows paint } \\
\text { deterioration }\end{array}$ & $\checkmark$ & $\checkmark$ & $\checkmark$ & - & - \\
\hline $\begin{array}{l}\text { Internal gutters } \\
\text { leaking }\end{array}$ & $\checkmark$ & $\checkmark$ & $\checkmark$ & $\begin{array}{l}\text { Combined with } \\
\text { Signs of leaking } \\
\text { indoors }(\max =1) \\
\text { No }=0 \\
\text { Yes }=1\end{array}$ & - \\
\hline $\begin{array}{l}\text { Spouting and } \\
\text { guttering } \\
\text { holes }\end{array}$ & $\checkmark$ & $\checkmark$ & $\checkmark$ & $\begin{array}{l}\text { Number of } \\
\text { spouting/ } \\
\text { guttering defects }\end{array}$ & - \\
\hline $\begin{array}{l}\text { Guttering - } \\
\text { reverse flow }\end{array}$ & $\checkmark$ & $\checkmark$ & $\checkmark$ & $0-5$ & \\
\hline $\begin{array}{l}\text { Spouting and } \\
\text { guttering } \\
\text { joint leaks }\end{array}$ & $\checkmark$ & $\checkmark$ & $\checkmark$ & & \\
\hline $\begin{array}{l}\text { Spouting and } \\
\text { guttering } \\
\text { corrosion }\end{array}$ & $\checkmark$ & $\checkmark$ & $\checkmark$ & & \\
\hline $\begin{array}{l}\text { Missing } \\
\text { guttering/ } \\
\text { downpipes }\end{array}$ & $\checkmark$ & $\checkmark$ & $\checkmark$ & & \\
\hline
\end{tabular}

and floor joists).

\subsection{Moisture measurements}

Percentage moisture content (\%MC) was measured using a twopronged electrical resistance meter (Protimeter CEM DT-125) in the timber structural framing of houses where access to roof space or subfloor allowed. Protimeters were chosen because they are a standard instrument used in the construction industry in New Zealand and were found to be "potentially useful" in a 2018 review of the literature [39]. The instruments were calibrated once at the start of each study.

In the ceiling joists, a single measurement was taken. In the floor joists, two measurements were taken from different joists at least $1.5 \mathrm{~m}$ apart, the results of which were averaged for subsequent analyses. The instruments were calibrated at the start of each study. They were not recalibrated and repeatability testing was not conducted.

\subsection{Climate data}

For each house, we obtained 24-h rainfall and daily maximum temperatures for a 30-day period prior to the date of the survey. Data was sourced from the National Climate database [40] from the weather station closest to the house (generally within $<10 \mathrm{~km}$ ). Data were expressed as 30 -day total rainfall $(\mathrm{mm})$ and mean 30 daily maximum temperature $\left({ }^{\circ} \mathrm{C}\right)$.

\subsection{Data analyses}

Analyses were conducted for each HCS separately using STATA 15 (StataCorp LP, TX, USA). Associations between home characteristics and subjective damp were assessed using logistic regression adjusting for other co-variates. House characteristic variables tested are listed in Table 2. As there were a large number of home characteristics that could potentially be associated with indicators of home dampness, we initially conducted univariate (or unadjusted analyses) for each of these variables. We subsequently conducted multivariable regression analyses (mutually adjusting for other potential confounders). For these analyses we only included variables that met one of two requirements: 1) in unadjusted analyses, associations were consistent and borderline statistically significant $(\mathrm{p} \leq 0.1$ ) for that variable in two or more of the surveys; or 2) consistent associations with damp were observed across all three surveys, and statistically significant $(\mathrm{p} \leq 0.05)$ in at least one. This approach was used to reduce the number of variables in these models, thus increasing statistical power and reducing risk of multicollinearity. In the results section we describe only the fully adjusted analyses based on these multivariable models. For measured moisture, linear regression was used following the same approach. All models were further adjusted for surveyor, by including surveyor ID as an independent categorical variable (except 2005, as the surveyor who undertook the house assessment was highly correlated with the variable for climate zone, thus resulting in multi-collinearity), average 30-day rain $(\mathrm{mm})$ and 30-day average maximum temperature $(\mathrm{oC})$. A flow chart visualising the analysis process has been included in the supplementary materials (Fig. S1).

In addition to considering individual house characteristics, we also conducted analyses involving aggregated variables by combining variables within the same domains. Prior to doing so, we checked for consistency of associations (negative or positive) for each individual variable. The aggregated variable for mechanical ventilation involved combining information on independently operated kitchen, bathroom and clothes dryer external ducting into one variable (with each fan/duct controlling a particular moisture point source). For this purpose, we used a score of " 1 " for the presence, and " 0 " for the absence of each of these ventilation types, and this was summed for each house and subsequently used in the analysis (the total sum variable ranged from zero to three). For the insulation domain, the presence of roof, underfloor and 
wall cavity insulation (using the assumptions described above under "House characteristics" for wall insulation) were summed, resulting in a score ranging from zero (no insulation) to three (all three areas insulated). The subfloor domain summed the presence of ponding or leaks, insufficient subfloor ventilation, and lack of ground moisture barrier, again resulting in a combined score ranging from zero to three. The building envelope condition (BEC) domain summed moderate to serious condition of; roof cladding, wall cladding, exterior paint, windows and spouting/guttering, with a combined score ranging from zero to five. These aggregate domains allowed dose-response associations within each domain to be assessed. In the analysis, houses with a score of three were used as the reference category for the insulation domain, due to low numbers in the category with zero insulation. For all other aggregate variables, the houses with a combined score of zero were used as the reference category. Details about how variables were categorised and aggregated for inclusion in both multivariate and analysis within domains are presented in Table 2 .

In addition to measuring associations using the BEC domain as described above, we also conducted analyses using the overall condition rating (OCR) provided by the assessors at the end of the survey as a single summary condition rating for the house rated on a 3-point scale: well maintained, moderately maintained or poorly maintained. This was based on the assessors' judgement of all maintenance needed anywhere in the house, to bring it to "as new" standard. Materials and fittings, both inside and out, were included in the assessment, and the presence of mould was considered a condition in need of maintenance.

Tests for trend were conducted by converting each summed categorical domain to a continuous variable in regression analyses and using the resultant p-value. Collinearity was tested for all models using variance inflation factors, and all scores were under three.

\section{Results}

The three HCSs differed with regards to the season in which they were conducted i.e. in 2010 the majority of houses were assessed in the colder and wetter months of winter and spring, whereas the 2005 survey was conducted almost entirely in summer (Table 1). The age distribution of the houses across the three surveys was similar, with around half built between 1930 and 1979, a third built after 1979, and 11\%-15\% built before 1930. Houses in the 2010 and 2015 surveys, which included rental properties ( $22 \%$ and $27 \%$, respectively), were more likely to have fewer bedrooms and occupants (Table 1). The 2010 survey included a lower proportion of well-maintained houses (25\%) compared to the 2005 (50\%) and 2015 (44\%) surveys.

Subjective dampness was reported most frequently in 2010 (26\%), compared to $12 \%$ in 2005 , and $15 \%$ in 2015 . Roof moisture and 30 -day rainfall was also highest in 2010 (Table 1). In contrast, floor joist moisture was highest in the 2005 survey (19.2\% moisture content (MC)) compared to approximately $16.5 \%$ MC for the two later surveys. Histograms demonstrating the range of moisture measurements are presented in Fig. 1.

\subsection{Subjective dampness}

The presence of a rangehood, or extract ventilation over the cooker, was associated with less dampness in the 2010 and 2015 surveys (aORs 0.5 and $0.3, \mathrm{p}<0.05$; Table 3 ), but no association was found in the 2005 survey. Houses with the least ceiling space insulation (an index combining thickness and proportion of the ceiling covered) had a greater risk of dampness, statistically significant for the 2005 (aOR 3.1, $\mathrm{p}<0.05$ ) and 2015 surveys (aOR 4.7, $\mathrm{p}<0.05$ ). Additional analyses adjusting for the cumulative presence of ceiling insulation defects (gaps, settling, poor fit and general damage) did not appreciably change these results (data not shown). Ponding or leaks in the subfloor space were associated with increased indoor dampness, but this reached statistical significance only in the 2010 survey (aOR 2.1 to $2.6, \mathrm{p}<0.05$ in 2010 only). Poor window condition was also associated with more dampness (aORs 2.0 to 4.8), statistically significant $(\mathrm{p}<0.001$ ) in the 2015 survey, and borderline statistically significant $(\mathrm{p}<0.1)$ in the other two surveys. Fibre-cement cladding was associated with significantly increased odds of indoor dampness (aORs 2.3 to 6.3; Table 3) and this was statistically significant ( $\mathrm{p}<0.05$ ) in both the 2005 and 2010 surveys (Table 3 ).

Analyses using aggregated variables showed that the presence of multiple mechanical ventilation types (rangehood, bathroom and clothes dryer vented to outdoors) was consistently associated, in a dosedependent fashion, with less indoor dampness (aORs 0.3 to 0.5 , for two or three types of ventilation present; $p$ for trend $<0.05$ in 2010 and 2015; Table 4). Dose-response trends were also demonstrated for BEC defects in all three surveys, with houses with four or five defects being 6.4 to 9.6 times more likely to be characterised as damp ( $\mathrm{p}$ for trend
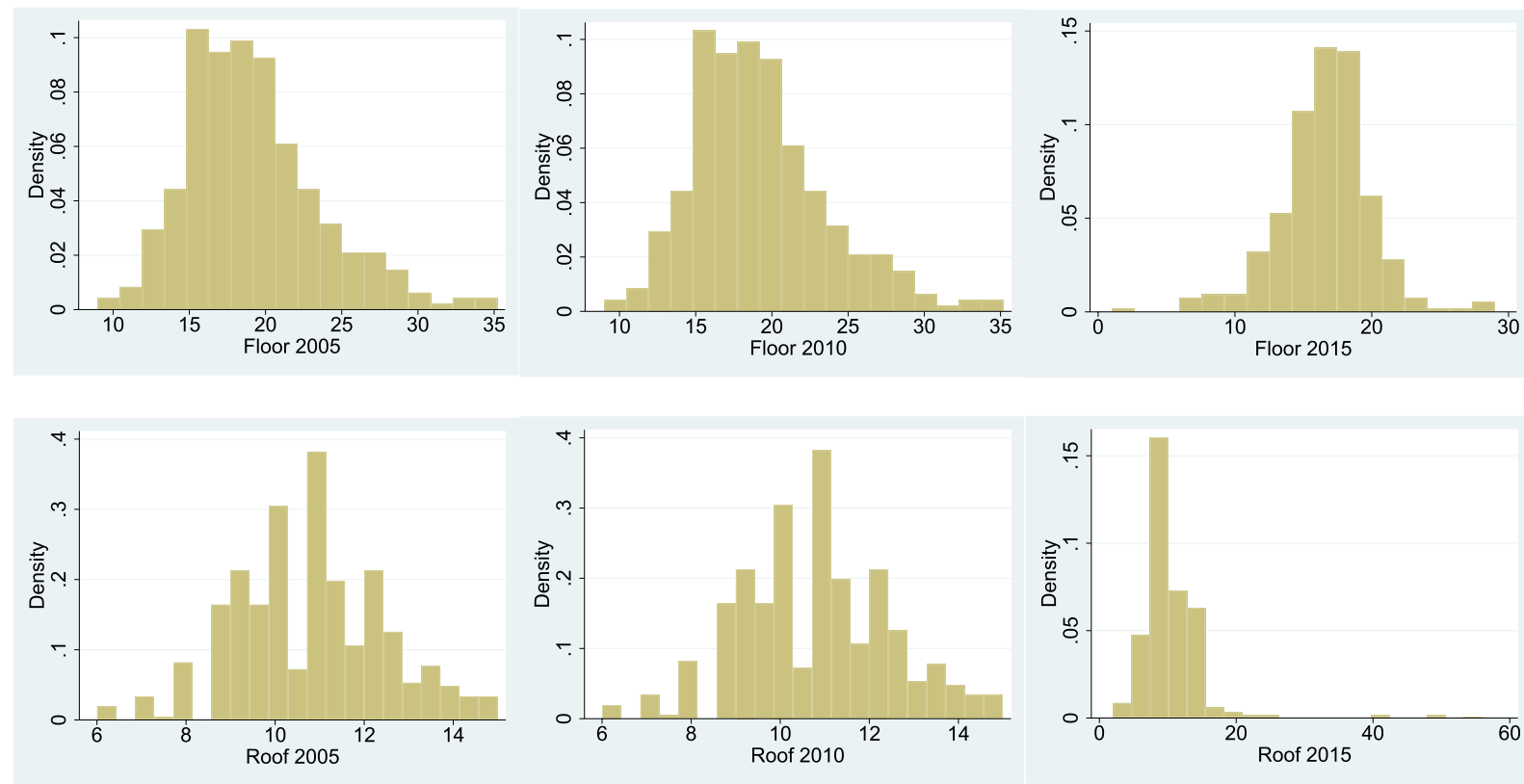

Fig. 1. Histograms showing moisture content in floor and ceiling joists. 
Table 3

Multiple regression analysis of subjective dampness in 3 House Condition Surveys.

\begin{tabular}{|c|c|c|c|c|c|c|c|c|c|}
\hline & \multirow[t]{3}{*}{$N$} & \multirow[t]{3}{*}{$n$} & \multirow{2}{*}{$\begin{array}{l}\frac{2005}{\mathrm{~N}=565 / \mathrm{n}=63 \mathrm{P}=0.0003 \mathrm{R}^{2}} \\
=0.14\end{array}$} & \multirow[t]{2}{*}{ 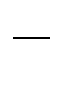 } & \multirow{2}{*}{-} & \multicolumn{2}{|l|}{2010} & \multirow{2}{*}{ - } & \multirow{2}{*}{$\begin{array}{l}2015 \\
\mathrm{~N}=520 / \mathrm{n}=78 \mathrm{P}<0.0000 \mathrm{R}^{2} \\
=0.41\end{array}$} \\
\hline & & & & & & $\begin{array}{l}\mathrm{N}=346 / \mathrm{n}=91 \mathrm{P}<0.0000 \mathrm{R}^{2} \\
=0.31\end{array}$ & & & \\
\hline & & & aOR $(95 \% \mathrm{CI})$ & $N$ & $n$ & aOR $(95 \% \mathrm{CI})$ & $N$ & $n$ & aOR $(95 \% \mathrm{CI})$ \\
\hline \multicolumn{10}{|l|}{ Occupants } \\
\hline 1 to 2 & 273 & 21 & Ref & 202 & 45 & Ref & 315 & 50 & Ref \\
\hline 3 to 4 & 213 & 31 & $2.2(1.2,4.2)^{* *}$ & 117 & 38 & $1.3(0.7,2.5)$ & 159 & 16 & $0.4(0.2,0.9)^{*}$ \\
\hline 5 or more & 63 & 10 & $1.7(0.7,4.2)$ & 27 & 8 & $1.2(0.4,4.0)$ & 46 & 12 & $2.3(0.8,7.0)^{\wedge}$ \\
\hline missing & 16 & 1 & $0.9(0.1,7.8)$ & & & & & & \\
\hline \multicolumn{10}{|l|}{ Tenure } \\
\hline Owner occupied & & & & 272 & 67 & Ref & 386 & 46 & Ref \\
\hline Rented & & & NA & 74 & 24 & $1.6(0.7,3.6)$ & 134 & 32 & $2.2(1.0,4.8)^{*}$ \\
\hline \multicolumn{10}{|l|}{ Range hood } \\
\hline No & 342 & 42 & Ref & 136 & 50 & Ref & 191 & 52 & Ref \\
\hline Vented to outside & 223 & 21 & $1.1(0.6,2.1)$ & 210 & 41 & $0.5(0.2,1.0)^{*}$ & 329 & 26 & $0.3(0.1,0.6)^{* * *}$ \\
\hline \multicolumn{10}{|l|}{ Bathroom ventilation } \\
\hline None & 312 & 38 & Ref & 178 & 57 & Ref & 202 & 41 & Ref \\
\hline Vented to outside & 164 & 14 & $0.9(0.4,1.9)$ & 145 & 30 & $1.2(0.6,2.4)$ & 258 & 27 & $0.7(0.3,1.4)$ \\
\hline Vented to roof space & 89 & 11 & $1.1(0.5,2.6)$ & 23 & 4 & $1.2(0.3,4.7)$ & 34 & 6 & $0.9(0.3,3.4)$ \\
\hline missing & & & & & & & 26 & 4 & $0.8(0.2,4.5)$ \\
\hline \multicolumn{10}{|l|}{ Wall insulation } \\
\hline No & 326 & 46 & Ref & 228 & 73 & Ref & 125 & 29 & Ref \\
\hline Yes & 239 & 17 & $0.9(0.5,2.0)$ & 118 & 18 & $0.5(0.2,1.3)$ & 135 & 12 & $1.0(0.3,2.9)$ \\
\hline missing & & & & & & & 260 & 37 & $0.6(0.3,1.6)$ \\
\hline \multicolumn{10}{|l|}{ Ceiling insulation } \\
\hline Most & 421 & 35 & Ref & 203 & 52 & Ref & 213 & 30 & Ref \\
\hline Mid & 101 & 18 & $2.4(1.2,4.8)^{* *}$ & 75 & 18 & $0.7(0.3,1.6)$ & 214 & 28 & $1.4(0.6,3.0)$ \\
\hline Least & 43 & 10 & $3.1(1.3,7.8)^{* *}$ & 11 & 4 & $1.4(0.3,6.9)$ & 25 & 10 & $4.2(1.3,13.9)^{*}$ \\
\hline Missing & & & & 57 & 17 & $1.5(0.6,3.8)$ & 68 & 10 & $0.8(0.3,2.4)$ \\
\hline $\begin{array}{l}\text { Subfloor ventilation } \\
\text { sufficient }\end{array}$ & & & & & & & & & \\
\hline Yes & 162 & 25 & Ref & 46 & 12 & Ref & 94 & 19 & $R e f$ \\
\hline No & 267 & 32 & $0.7(0.4,1.3)$ & 182 & 62 & $1.6(0.6,4.5)$ & 212 & 45 & $1.3(0.5,3.1)$ \\
\hline Slab foundation & 136 & 6 & $0.4(0.2,1.2)$ & 120 & 17 & $1.3(0.4,4.14)$ & 214 & 14 & $0.4(0.1,1.2)$ \\
\hline Missing & & & & & & & & & \\
\hline Ponding/leaks under $h$ & & & & & & & & & \\
\hline No & 528 & 56 & Ref & 285 & 62 & Ref & 462 & 57 & $R e f$ \\
\hline Yes & 37 & 7 & $2.6(0.7,9.8)$ & 61 & 29 & $2.6(1.1,6.2)^{*}$ & 58 & 21 & $2.1(0.7,6.6)$ \\
\hline Roof condition rating & & & & & & & & & \\
\hline Excellent/Good & 414 & 39 & Ref & 200 & 33 & $\operatorname{Ref}$ & 286 & 28 & Ref \\
\hline Moderate/poor/serious & 151 & 24 & $1.2(0.6,2.2)$ & 126 & 51 & $1.8(0.9,3.5)^{\wedge}$ & 216 & 49 & $1.4(0.6,3.4)$ \\
\hline Missing & & & & 20 & 7 & $2.3(0.5,10.2)$ & 18 & 1 & $0.3(0.3,4.1)$ \\
\hline Window condition & & & & & & & & & \\
\hline Excellent/Good & 385 & 26 & Ref & 172 & 25 & Ref & 297 & 22 & Ref \\
\hline Moderate/poor/serious & 180 & 37 & $2.0(1.0,4.0)^{\wedge}$ & 164 & 67 & $2.1(0.9,4.9)^{\wedge}$ & 223 & 56 & $3.9(1.5,10.1)^{* *}$ \\
\hline Missing & & & & 10 & 5 & $2.1(0.4,12.6)$ & & & \\
\hline $\begin{array}{l}\text { Wall cladding paint } \\
\text { deterioration }\end{array}$ & & & & & & & & & \\
\hline No & 280 & 24 & Ref & 254 & 60 & Ref & 365 & 32 & Ref \\
\hline Yes & 285 & 39 & $1.3(0.7,2.3)$ & 92 & 31 & $1.9(0.8,4.2)$ & 155 & 46 & $3.4(1.5,7.6)^{* *}$ \\
\hline Wall cladding conditio & & & & & & & & & \\
\hline Excellent/Good & 414 & 31 & Ref & 81 & 17 & Ref & 307 & 28 & Ref \\
\hline Moderate/poor/serious & 151 & 32 & $1.8(0.9,3.6)^{\wedge}$ & 251 & 70 & $0.6(0.2,1.5)$ & 214 & 50 & $1.8(0.8,4.4)$ \\
\hline Missing & & & & 14 & 4 & $1.1(0.2,6.5)$ & & & \\
\hline Cladding type & & & & & & & & & \\
\hline Timber weatherboards & 186 & 23 & Ref & 74 & 30 & Ref & 117 & 22 & $R e f$ \\
\hline Fibre-cement & 55 & 9 & $3.0(1.1,8.7)^{*}$ & 28 & 11 & $6.2(1.6,23.9)^{* *}$ & 69 & 11 & $2.0(0.6,6.7)$ \\
\hline Brick & 86 & 7 & $2.3(0.8,6.4)$ & 40 & 10 & $0.9(0.3,3.1)$ & 104 & 7 & $2.2(0.6,8.3)$ \\
\hline Mixed/other & 238 & 24 & $1.4(0.7,2.9)$ & 204 & 40 & $1.1(0.5,2.3)$ & 231 & 38 & $2.4(0.9,5.9)^{\wedge}$ \\
\hline Spouting condition & & & & & & & & & \\
\hline Excellent/good & 452 & 44 & Ref & 210 & 37 & Ref & 332 & 36 & $\operatorname{Ref}$ \\
\hline Moderate/poor/serious & 113 & 19 & $1.0(0.5,2.0)$ & 108 & 46 & $2.2(1.1,4.6)^{*}$ & 188 & 42 & $1.2(0.5,2.9)$ \\
\hline Missing & & & & 28 & 8 & $1.3(0.4,4.7)$ & & & \\
\hline
\end{tabular}

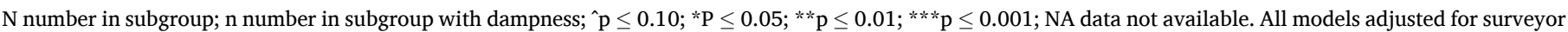
(except 2005 because of collinearity with zone), 30 day rain ( $\mathrm{mm}$ ), 30 day mean high temperature $\left({ }^{\circ} \mathrm{C}\right)$, indoor plumbing leaks \& window material.

$<0.001)$. We also found a strong association between overall condition rating (OCR) and indoor dampness with aORs ranging from 20.6 to 47.8 comparing poor versus excellent condition ( $\mathrm{p}$ for trend $<0.001$ for all three surveys, Table 4). A consistent dose-response pattern was also found with aggregated subfloor defects, although the trend was statistically significant only in 2010 and 2015 (p for trend $<0.01$ ).

\subsection{Floor and roof joist moisture measurements}

Presence of a ground vapour barrier over more than $50 \%$ of the ground under the house was associated with a $0.1-1.9 \%$ reduction in floor joist moisture content, statistically significant in the 2015 survey ( $\mathrm{p}<0.001)$ and borderline significant in the 2010 survey $(\mathrm{p}<0.1$; Table 5). Presence of ponding or leaks was associated with a $0.7-2.3 \%$ 
Table 4

Analysis of aggregated variables of subjective indoor dampness in three house condition surveys.

\begin{tabular}{|c|c|c|c|c|c|c|c|c|c|}
\hline & \multirow[t]{2}{*}{$N$} & \multirow[t]{2}{*}{$n$} & \multirow{2}{*}{$\begin{array}{l}2005 \mathrm{~N}=565 / \mathrm{n}=63 \\
\mathrm{P}=0.0008 \mathrm{R}^{2}=0.11 \\
\text { aOR }\end{array}$} & \multirow[b]{2}{*}{$N$} & \multirow{2}{*}{$\bar{n}$} & \multirow{2}{*}{$\begin{array}{l}2010 \mathrm{~N}=345 / \mathrm{n}=91 \\
\mathrm{P}<0.0000 \mathrm{R}^{2}=0.28 \\
\mathrm{aOR}\end{array}$} & \multirow[b]{2}{*}{$N$} & \multirow{2}{*}{$\bar{n}$} & \multirow{2}{*}{$\begin{array}{l}2015 \mathrm{~N}=507 / \mathrm{n}=77 \mathrm{P} \\
<0.0000 \mathrm{R}^{2}=0.37 \\
\text { aOR }\end{array}$} \\
\hline & & & & & & & & & \\
\hline $\begin{array}{l}\text { Ventilation/3 (bath/ } \\
\text { cooker/dryer) } 0\end{array}$ & 239 & 31 & Ref & 97 & 40 & Ref & 124 & 33 & Ref \\
\hline 1 & 188 & 24 & $1.4(0.7,2.6)$ & 123 & 28 & $0.4(0.2,0.8)^{* *}$ & 167 & 31 & $0.7(0.4,1.5)$ \\
\hline 2 & 113 & 7 & $0.7(0.3,1.6)$ & 99 & 19 & $0.4(0.2,1.0) *$ & 183 & 11 & $0.3(0.1,0.6)^{* * *}$ \\
\hline 3 & 25 & 1 & $0.3(0.4,2.8)$ & 26 & 4 & $0.3(0.1,1.2)^{\wedge}$ & 33 & 2 & $0.3(0.0,2.0)$ \\
\hline Trend & & & NS & & & $\mathrm{P}<0.05$ & & & $\mathrm{P}<0.01$ \\
\hline \multicolumn{10}{|l|}{ Insulation/3 (roof/ } \\
\hline Wall/underfloor or slab) 3 & 211 & 12 & Ref & 97 & 12 & Ref & 115 & 9 & Ref \\
\hline 2 & 153 & 21 & $1.8(0.8,4.1)$ & 135 & 34 & $1.6(0.6,3.9)$ & 297 & 41 & $1.5(0.5,4.3)$ \\
\hline 1 & 173 & 23 & $1.6(0.7,3.8)$ & 108 & 44 & $2.3(0.9,6.3)^{\wedge}$ & 87 & 22 & $2.5(0.7,8.2)$ \\
\hline No insulation & 28 & 7 & $2.9(0.9,9.9)^{\wedge}$ & 5 & 1 & $1.0(0.1,12.9)$ & 8 & 5 & $7.5(1.1,49.9) *$ \\
\hline Trend & & & NS & & & $P=0.05$ & & & $P=0.09$ \\
\hline \multicolumn{10}{|l|}{ Subfloor/3 (ventilation/ } \\
\hline 1 & 193 & 25 & $1.3(0.6,2.9)$ & 268 & 60 & $3.4(0.8,14.8)$ & 136 & 28 & $3.2(1.3,7.7)^{* *}$ \\
\hline 2 & 162 & 22 & $1.4(0.6,3.5)$ & 57 & 28 & $7.3(1.5,36.7)^{*}$ & 144 & 21 & $1.8(0.7,4.5)$ \\
\hline 3 & 22 & 4 & $1.7(0.4,7.2)$ & & & & 23 & 14 & $15.4(3.8,62.8)^{* * *}$ \\
\hline Trend & & & NS & & & $\mathrm{P}<0.01$ & & & $\mathrm{P}<0.01$ \\
\hline \multicolumn{10}{|c|}{$\begin{array}{l}\text { BEC/5 (Poorer condition of; roof cladding/wall } \\
\text { cladding/windows/exterior paint/spouting and } \\
\text { guttering) }\end{array}$} \\
\hline $0-1$ & 329 & 19 & Ref & 103 & 12 & Ref & 229 & 14 & Ref \\
\hline $2-3$ & 175 & 29 & $2.8(1.5,5.2)^{* *}$ & 117 & 31 & $2.0(0.8,4.6)$ & 137 & 26 & $3.4(1.5,8.0)^{* * *}$ \\
\hline $4-5$ & 61 & 15 & $3.9(1.8,8.8)^{* * *}$ & 64 & 31 & $6.4(2.4,16.9)^{* * *}$ & 141 & 37 & $9.6(3.8,23.9)^{* * *}$ \\
\hline Missing & & & & 61 & 17 & $2.4(0.9,6.4)^{\wedge}$ & & & \\
\hline Trend & & & $\mathrm{P}<0.001$ & & & $\mathrm{P}<0.001$ & & & $\mathrm{P}<0.001$ \\
\hline \multicolumn{10}{|l|}{ OCR } \\
\hline Excellent & 280 & 6 & Ref & 117 & 3 & Ref & 231 & 5 & Ref \\
\hline Moderate & 195 & 26 & $6.5(2.6,16.7)^{* * *}$ & 122 & 29 & $10.5(2.8,38.8)^{* * *}$ & 210 & 37 & $8.9(3.1,26.0)^{* * *}$ \\
\hline $\begin{array}{l}\text { Poor } \\
\text { missing }\end{array}$ & 90 & 31 & $20.6(7.7,55.3)^{* * * *}$ & 104 & 59 & $47.8(12.1,188.4)^{* * *}$ & 88 & 36 & $37.2(10.8,127.7)^{* * *}$ \\
\hline Trend & & & $\mathrm{P}<0.001$ & & & $\mathrm{P}<0.001$ & & & $\mathrm{P}<0.001$ \\
\hline
\end{tabular}

$\mathrm{N}$ number in subgroup; $\mathrm{n}$ number in subgroup with dampness; ${ }^{\wedge} \mathrm{p} \leq 0.10 ;{ }^{*} \mathrm{P} \leq 0.05 ;{ }^{* *} \mathrm{p} \leq 0.01 ; * * * \mathrm{p} \leq 0.001$; NS not significant. All models adjusted for surveyor (except 2005 because of collinearity with zone), 30 day rain $(\mathrm{mm}), 30$ day mean high temperature $\left({ }^{\circ} \mathrm{C}\right.$ ), occupancy \& tenure.

increase in floor joist moisture content, significant $(\mathrm{p}<0.05)$ in both the 2005 and 2010 surveys. Poorer condition of the roof cladding was also associated with a small increase $(0.4-0.6 \%)$ in floor joist moisture content, significant $(\mathrm{p}<0.05)$ only in the 2010 survey (Table 5).

There were few consistent associations between moisture content of the roof framing and other variables, although roofs that were clad with concrete or brick tiles were associated with an increase in moisture levels $(0.9 \%-1.2 \%)$ compared to roofs clad with a metal cladding material; this association was statistically significant $(\mathrm{p}<0.001)$ in both the 2005 and 2010 surveys (Table 6). Also, compared to the oldest houses (built before 1930), moisture content of roof framing in newer houses was progressively lower (1930s-1970s, $-0.6 \%$ to $-0.7 \%$; and 1980 and newer $-0.9 \%$ ) in the 2005 and 2010 surveys, although this relationship was significant $(\mathrm{p}<0.05$ ) only in the 2005 survey.

Combined subfloor defects were consistently associated with increased floor joist moisture $(1.2 \%-3.7 \%, \mathrm{p}<0.01$ for houses with two or three (of three) defects; Table 7). BEC defects were also associated with increased moisture content in the floor joists (1.8\% and $1.5 \%)$ for houses with two or three (of five) building envelope defects present, in 2005 and 2015 respectively, with a significant trend shown in 2015 (p $<$ 0.01 ; Table 7). Using the assessors' overall condition rating (OCR), a significant trend with moisture content in the floor joist was shown in the 2015 survey ( $<<0.05$ ), but the relationship was weaker than for BEC variables. We also found that the presence of less insulation types was associated, in a dose-dependent fashion, with increased moisture content in roof joists in the 2005 survey (Table 7); this trend was significant also in 2010, but no association was observed in the 2015 survey.

\section{Discussion}

This study showed that specific subfloor and BEC defects were associated with increases in both subjectively assessed indoor dampness and objectively measured moisture in floor joists, whereas other house characteristics, such as fewer ventilation and insulation factors, more occupants, tenure type (rented), and poorer inspector-assessed overall condition rating (OCR), were associated only with increased indoor subjective dampness but not with either floor joist or ceiling joist moisture content. Older houses, and houses with concrete or brick tile roofs (compared to metal cladding materials) were associated with higher moisture content readings in the ceiling joist, but not with either subjective indoor damp or floor joist moisture.

\subsection{Subjective indoor dampness}

Building envelope condition defects were generally associated with increased indoor dampness, with a significant dose-response pattern observed for the aggregated variable in all three surveys. Consistent with this, and using data from the same three surveys, we have previously shown a similar association between BEC and both indoor visible mould and musty odour (both inspector-assessed) [24]. A study from Quebec that assessed self-reported dampness in 2097 student dormitory rooms also found a dose-response association between poor repairs and increased dampness [16], whilst two other studies found increased mould in houses with poor repairs [23,41]. Unlike our study that assessed associations with individual aspects of poor repairs/building defects (Table 2), these studies did not further characterise "poor repair", thus hampering the development of specific interventions beyond "more regular maintenance". 
Table 5

Multiple regression analysis of floor joist moisture measurements in 3 House Condition Surveys.

\begin{tabular}{|c|c|c|c|c|c|c|}
\hline & \multirow[t]{3}{*}{$n$} & \multirow{2}{*}{$\begin{array}{l}2005 \\
N=326 P<0.0000 R^{2}=0.56\end{array}$} & \multirow{3}{*}{$\overline{-}$} & \multirow{3}{*}{$\frac{2010}{\mathrm{~N}=285 \mathrm{P}<0.0000 \mathrm{R}^{2}=0.60}$} & \multirow{3}{*}{$\bar{n}$} & \multirow{3}{*}{$\begin{array}{l}\frac{2015}{\mathrm{~N}=321 \mathrm{P}<0.0000 \mathrm{R}^{2}=0.44} \\
\text { Coefficient }(95 \% \mathrm{CI})\end{array}$} \\
\hline & & & & & & \\
\hline & & Coefficient (95\% CI) & & & & \\
\hline \multicolumn{7}{|l|}{ Range hood } \\
\hline No & 187 & $\operatorname{Ref}$ & 155 & $\operatorname{Ref}$ & 166 & Ref \\
\hline Vented to outside & 139 & $-0.0(-0.8,0.8)$ & 130 & $-0.3(-0.8,0.3)$ & 155 & $0.7(-0.0,1.4)^{*}$ \\
\hline \multicolumn{7}{|l|}{ Vented to roof space } \\
\hline \multicolumn{7}{|l|}{ Bathroom ventilation } \\
\hline None & 178 & Ref & 150 & Ref & 134 & $\operatorname{Ref}$ \\
\hline Vented to outside & 89 & $0.4(-0.5,1.3)$ & 104 & $0.1(-0.4,0.6)$ & 142 & $0.3(-0.4,1.0)$ \\
\hline Vented to roof space & 59 & $0.3(-0.7,1.3)$ & 31 & $0.1(-0.7,0.8)$ & 26 & $-0.2(-1.4,1.1)$ \\
\hline missing & & & & & 19 & $0.7(-0.8,2.3)$ \\
\hline \multicolumn{7}{|l|}{ Ceiling insulation } \\
\hline Most & 244 & Ref & 154 & Ref & 143 & Ref \\
\hline Mid & 52 & $-0.3(-1.3,0.8)$ & 78 & $0.3(-0.2,0.9)$ & 126 & $-0.5(-1.2,0.3)$ \\
\hline Least & 30 & $-0.2(-1.4,1.1)$ & 11 & $1.9(0.7,3.2)^{* * *}$ & 16 & $-0.2(-1.8,1.4)$ \\
\hline Missing & & & 42 & $0.2(-0.5,0.9)$ & 36 & $-0.9(-2.0,0.21)$ \\
\hline \multicolumn{7}{|l|}{ Subfloor ventilation sufficient } \\
\hline Yes & 123 & Ref & 68 & Ref & 89 & Ref \\
\hline No & 203 & $1.1(0.3,1.8)^{* *}$ & 192 & $0.6(0.0,1.3)^{*}$ & 195 & $0.6(-0.2,1.4)$ \\
\hline Slab foundation & & & 25 & $-0.5(-1.5,0.5)$ & 37 & $0.4(-0.8,1.7)$ \\
\hline \multicolumn{7}{|l|}{ Missing } \\
\hline \multicolumn{7}{|l|}{ Ground cover under house } \\
\hline Piles \& $0-50 \%$ ground covered & 237 & Ref & 229 & Ref & 230 & Ref \\
\hline Piles \& $>50 \%$ ground covered & 6 & $-0.1(-2.6,2.9)$ & 31 & $-0.6(-1.3,0.1)^{\wedge}$ & 60 & $-1.9(-2.8,-1.0)^{* * *}$ \\
\hline Slab foundation & 83 & $-0.0(-0.9,0.8)$ & 25 & $-1.1(-2.3,0.0)^{\wedge}$ & 5 & $-5.3(-8.7,-1.9)^{* * *}$ \\
\hline missing & & & & & 26 & $-1.2(-3.2,0.8)$ \\
\hline \multicolumn{7}{|l|}{ Ponding/leaks under house } \\
\hline No & 292 & $\operatorname{Ref}$ & 222 & $\operatorname{Ref}$ & 262 & Ref \\
\hline Yes & 34 & $2.3(0.4,4.2)^{*}$ & 63 & $0.8(0.14,1.4)^{*}$ & 59 & $0.7(-0.4,1.7)$ \\
\hline \multicolumn{7}{|l|}{ Roof condition rating } \\
\hline Excellent/Good & 216 & Ref & & $\operatorname{Ref}$ & 165 & Ref \\
\hline Moderate/poor/serious & 110 & $0.5(-0.3,1.2)$ & & $0.6(0.1,1.1)^{*}$ & 150 & $0.4(-0.5,1.3)$ \\
\hline Missing & & & & $0.6(-0.6,1.7)$ & 6 & $-1.2(-3.7,1.3)$ \\
\hline \multicolumn{7}{|l|}{ Window condition } \\
\hline Excellent/Good & 206 & Ref & 118 & Ref & 151 & Ref \\
\hline Moderate/poor/serious & 120 & $0.7(-0.2,1.5)^{\wedge}$ & 157 & $-0.1(-0.6,0.4)$ & 168 & $-0.1(-1.0,0.8)$ \\
\hline Missing & & & 10 & $-0.6(-1.9,0.6)$ & 2 & $-2.4(-6.7,1.9)$ \\
\hline \multicolumn{7}{|l|}{ Wall cladding condition } \\
\hline Excellent/Good & 222 & Ref & 55 & $\operatorname{Ref}$ & 165 & Ref \\
\hline Moderate/poor/serious & 104 & $0.1(-0.8,1.0)$ & 218 & $0.0(-0.6,0.7)$ & 153 & $0.4(-0.5,1.3)$ \\
\hline \multicolumn{7}{|l|}{ Missing } \\
\hline \multicolumn{7}{|l|}{ Cladding type } \\
\hline Timber weatherboards & 137 & Ref & 71 & Ref & 102 & Ref \\
\hline Fibre-cement & 34 & $0.6(-0.7,2.0)$ & 28 & $0.3(-0.6,1.1)$ & 46 & $0.5(-0.6,1.6)$ \\
\hline Brick & 30 & $-0.9(-2.3,0.5)$ & 25 & $0.6(-0.4,1.5)$ & 43 & $0.0(-1.2,1.3)$ \\
\hline Mixed/other & 125 & $-0.1(-1.0,0.8)$ & 161 & $0.2(-0.4,0.8)$ & 130 & $0.5(-0.4,1.3)$ \\
\hline \multicolumn{7}{|l|}{ Spouting condition } \\
\hline Excellent/good & 253 & Ref & 176 & Ref & 185 & Ref \\
\hline Moderate/poor/serious & 73 & $0.5(-0.4,1.5)$ & 94 & $-0.1(-0.6,0.5)$ & 134 & $0.9(0.0,1.8)^{*}$ \\
\hline Missing & & & 15 & $1.2(0.1,2.3)^{*}$ & 2 & $-4.0(-8.2,0.4)^{\wedge}$ \\
\hline
\end{tabular}

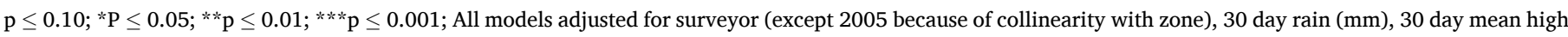

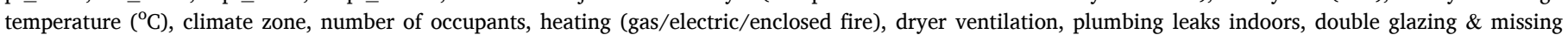
flashings.

In our study, the presence of insulation in fewer parts of the building envelope (ceiling, underfloor and wall cavity) was associated with increased indoor dampness. This is consistent with a large survey from Canada, which found that "improved insulation" was associated with reduced self-reported indoor dampness [18]. This is likely due to higher indoor temperatures, with warm air requiring fewer air changes to reduce indoor moisture [42]. Similar to our findings, two intervention studies reported reduced dampness following installation of insulation in ceiling cavities $[19,27]$. On the other hand, another study, involving a sample of homes with no wall or ceiling insulation and using a three-point scale for inspector reported dampness (dry/a little damp/very damp), showed that although underfloor insulation was inversely associated with the exposure category "a little damp", it did not reduce the odds of houses being categorised as "very damp" [43]. In addition to considering associations with indoor dampness indicators/measurements and ventilation and insulation separately, we also assessed the same associations using a combined insulation/ventilation variable (High/high, high/low, low/high, low/low insulation/ventilation). This showed that none of these pairings were consistently or significantly associated across surveys to subjective dampness or measured moisture (data not shown), suggesting that there was no clear interaction between insulation and ventilation.

A dose-response pattern of increased dampness with more (aggregated) subfloor defects in all three surveys was observed, with the presence of ponding and leaks under the house being significantly and independently associated also in the initial multivariate analysis (2010) using individual (non-aggregated) variables. This may be the due to warm indoor air creating a "stack effect", resulting in damp air from the subfloor space to be drawn upwards, thus infiltrating into the interior [51]. In contrast to our current findings, a previous study conducted by this research team, using data from the same three surveys, showed no association between subfloor defects and visible mould [24]. The reason 
Table 6

Multiple regression analysis of ceiling joist moisture measurements in 3 House Condition Surveys.

\begin{tabular}{|c|c|c|c|c|c|c|}
\hline & \multirow[t]{2}{*}{$n$} & \multirow{2}{*}{$\frac{2004 \mathrm{~N}=482 \mathrm{P}<0.0000 \mathrm{R}^{2}=0.24}{\text { Coefficient }(95 \% \mathrm{CI})}$} & \multirow{2}{*}{$\bar{n}$} & \multirow{2}{*}{$\frac{2010 \mathrm{~N}=373 \mathrm{P}<0.0000 \mathrm{R}^{2}=0.28}{\text { Coefficient }(95 \% \mathrm{CI})}$} & \multirow[b]{2}{*}{$n$} & \multirow{2}{*}{$\frac{2015 \mathrm{~N}=416 \mathrm{P}<0.0000 \mathrm{R}^{2}=0.21}{\text { Coefficient }(95 \% \mathrm{CI})}$} \\
\hline & & & & & & \\
\hline \multicolumn{7}{|l|}{ Age of house } \\
\hline Pre 1930 & 81 & Ref & 47 & Ref & 52 & Ref \\
\hline 1930-1979 & 267 & $-0.6(-1.1,-0.1)^{* *}$ & 183 & $-0.7(-1.7,0.4)$ & 233 & $-0.1(-1.8,1.6)$ \\
\hline Post 1980 & 132 & $-0.9(-1.6,-0.2)^{*}$ & 123 & $-0.9(-2.2,0.4)$ & 131 & $0.5(-1.8,2.7)$ \\
\hline \multicolumn{7}{|l|}{ Open fireplace } \\
\hline No & 390 & Ref & 339 & Ref & 393 & $\operatorname{Ref}$ \\
\hline Yes & 92 & $0.1(-0.3,0.5)$ & 34 & $0.1(-1.0,1.3)$ & 23 & $2.5(0.3,4.7)^{*}$ \\
\hline \multicolumn{7}{|c|}{ Subfloor ventilation sufficient } \\
\hline Yes & 125 & Ref & 58 & Ref & 71 & Ref \\
\hline No & 241 & $0.2(-0.1,0.6)$ & 193 & $0.7(-0.3,1.7)$ & 192 & $-0.1(-1.5,1.4)$ \\
\hline Slab foundation & 116 & $0.2(-0.3,0.6)$ & 122 & $0.4(-0.7,1.6)$ & 153 & $-0.4(-2.0,1.2)$ \\
\hline \multicolumn{7}{|l|}{ Missing } \\
\hline \multicolumn{7}{|l|}{ Roof material } \\
\hline Metal & 317 & Ref & 274 & Ref & 298 & $\operatorname{Ref}$ \\
\hline Concrete/clay tile & 160 & $0.9(0.5,1.2)^{* * *}$ & 91 & $1.2(0.4,2.0)^{* * *}$ & 96 & $0.3(-1.0,1.6)$ \\
\hline Missing/mixed/other & 5 & $-0.1(-1.4,1.3)$ & 8 & $0.9(-1.3,3.1)$ & 22 & $-0.1(-2.5,2.4)$ \\
\hline \multicolumn{7}{|l|}{ Roof condition rating } \\
\hline Excellent/Good & 353 & Ref & 216 & Ref & 246 & $\operatorname{Ref}$ \\
\hline Moderate/poor/serious & 129 & $-0.1(-0.4,0.2)$ & 138 & $0.3(-0.4,1.1)$ & 160 & $1.0(-0.2,2.2)$ \\
\hline Missing & & & 19 & $1.1(-0.4,2.5)$ & 10 & $-0.4(-3.7,2.9)$ \\
\hline \multicolumn{7}{|l|}{ Window condition } \\
\hline Excellent/Good & 326 & Ref & 189 & Ref & 151 & Ref \\
\hline Moderate/poor/serious & 156 & $-0.2(-0.5,0.1)$ & 173 & $0.6(-0.2,1.4)$ & 168 & $-0.6(-1.9,0.7)$ \\
\hline Missing & & & 11 & $0.4(-1.5,2.2)$ & 2 & $-1.3(-6.5,4.0)$ \\
\hline \multicolumn{7}{|l|}{ Cladding type } \\
\hline Timber weatherboards & 166 & Ref & 77 & Ref & 101 & Ref \\
\hline Fibre-cement & 45 & $-0.4(-1.0,0.2)$ & 29 & $-0.5(-1.9,0.9)$ & 51 & $0.6(-1.3,2.6)$ \\
\hline Brick & 80 & $-0.6(-1.1,-0.1)^{*}$ & 46 & $0.4(-0.8,1.6)$ & 87 & $-1.5(-3.2,0.3)^{\wedge}$ \\
\hline Mixed/other & 191 & $-0.4(-0.8,-0.0)^{*}$ & 221 & $-0.7(-1.6,0.2)$ & 177 & $-0.0(-1.4,1.4)$ \\
\hline
\end{tabular}

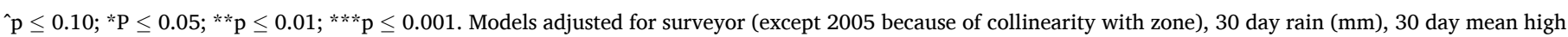
temperature $\left({ }^{\circ} \mathrm{C}\right)$, house age category, number of occupants, heating (gas/electric/open fire) \& wall insulation.

for this difference may be that subjective dampness and damp subfloor conditions are more closely associated with climatic conditions at the time of the survey than the presence of visible mould, which is more likely to be related to conditions over a longer time period.

To our knowledge, no other studies reported on the relationship between specific subfloor defects and indoor dampness. However, several studies have assessed associations with the presence of a subfloor (pile foundations), the results of which have been inconsistent. In particular, two studies, one from the USA and one from Finland, reported more indoor dampness for houses with a subfloor $[20,44]$ while a study from Sweden found the opposite [15]. A large study assessing associations with wet/dry basements reported that wet basements increased the risk of self-reported visible mould [45], however, this finding is not directly comparable to our study as basements with internal access and subterranean walls, are very different from houses constructed with pile foundations and subfloor spaces that do not have direct access to the house, as was the case for most of the houses in our sample.

Mechanical ventilation (extractor fans) was associated, in a dosedependent fashion, with less dampness. The presence of a rangehood over the cooker was particularly effective, reducing the odds of dampness to $<50 \%$, as observed in two of the three surveys. Our earlier study showed a similar dose-response for aggregated ventilation and reduced indoor mould, although no significant association was found when considering the presence of a rangehood by itself [24]. Other large surveys also found that the presence of a rangehood or kitchen fan was associated with a reduction in visible mould [45] or self-reported indoor dampness [22]. Similarly, a survey found that the presence of whole-house mechanical exhaust ventilation was associated with an approximately $50 \%$ reduced risk of floor moisture (visible damp patches) and condensation [15]. Similar effects of rangehoods and/or bathroom extractor fans on indoor damp and mould have also been reported in studies from Canada and China $[16,46]$. Mechanical ventilation reduces moisture by increasing the number of air changes per hour, thus replacing moist indoor air with air from outside that is generally drier [42]. Due to only a small number of houses in our sample having whole house ventilation systems, we were unable to assess the effectiveness of this compared to having extractor fans only in those rooms where most moisture is generated (kitchen and bathroom).

In the current study we found a strong dose-response association between the overall condition rating (OCR) of the house and indoor dampness, with more indoor dampness in poorly-compared to wellmaintained houses. This is similar to what we found previously for indoor mould and musty odour [24] and is consistent with other studies showing that an overall need of construction repairs or maintenance is associated with increased dampness or mould $[16,41,47]$. Since dampness and mould were considered by assessors as one of the indicators of a poor overall housing condition, this is perhaps not surprising. However, we also found strong associations with BEC, which was based on specific envelope components and did not include indoor dampness and mould.

The positive association between increased indoor dampness and fibre-cement cladding is of interest, particularly since questions surrounding weathertightness have been raised, and are currently being considered in the courts, in New Zealand. However, weathertightness was not assessed in this study, so we cannot ascertain with certainty whether the observed associations are related to this.

\subsection{Moisture measurements}

Ceiling joists of older houses and those with roofs clad with concrete or clay tiles were shown to have greater moisture content. The association with older houses may be due to the construction methods used to connect walls and ceilings in older New Zealand homes being less airtight compared to current methods [48], potentially resulting in indoor moisture infiltrating into the roof from activities inside [49]. Alternatively, or in addition, it may be due to residual confounding. In particular, although analyses were controlled for roof cladding condition, correctly identifying the condition of the roofs is difficult from a 
Table 7

Analysis of aggregated variables of ceiling and floor joist moisture in three house condition surveys.

\begin{tabular}{|c|c|c|c|c|c|c|c|c|c|c|c|c|}
\hline & \multicolumn{6}{|c|}{ Ceiling Joist Moisture } & \multicolumn{6}{|c|}{ Floor Joist Moisture } \\
\hline & \multirow[t]{2}{*}{$n$} & \multirow{2}{*}{$\begin{array}{l}2004 \mathrm{~N}= \\
482 \mathrm{P}< \\
0.0000 \mathrm{R}^{2}= \\
0.21 \\
\text { Coefficient } \\
(95 \% \mathrm{CI})\end{array}$} & \multirow{2}{*}{ - } & \multirow{2}{*}{$\begin{array}{l}2010 \mathrm{~N}= \\
373 \mathrm{P}< \\
0.0000 \mathrm{R}^{2}= \\
0.21 \\
\text { Coefficient } \\
(95 \% \mathrm{CI})\end{array}$} & \multirow[b]{2}{*}{$n$} & \multirow{2}{*}{$\begin{array}{l}2015 \mathrm{~N}= \\
400 \mathrm{P}< \\
0.0000 \mathrm{R}^{2}= \\
0.21 \\
\text { Coefficient } \\
(95 \% \mathrm{CI})\end{array}$} & \multirow[b]{2}{*}{$n$} & \multirow{2}{*}{$\begin{array}{l}2005 \mathrm{~N}= \\
326 \mathrm{P}< \\
0.0000 \mathrm{R}^{2}= \\
0.52 \\
\text { Coefficient } \\
(95 \% \mathrm{CI})\end{array}$} & \multirow[b]{2}{*}{$n$} & \multirow{2}{*}{$\begin{array}{l}2010 \mathrm{~N}= \\
285 \mathrm{P}< \\
0.0000 \mathrm{R}^{2}= \\
0.59 \\
\text { Coefficient } \\
(95 \% \mathrm{CI})\end{array}$} & \multirow[b]{2}{*}{$n$} & \multirow{2}{*}{$\begin{array}{l}2015 \mathrm{~N}= \\
310 \mathrm{P}< \\
0.0000 \mathrm{R}^{2}= \\
0.38 \\
\text { Coefficient } \\
(95 \% \mathrm{CI})\end{array}$} \\
\hline & & & & & & & & & & & & \\
\hline \multicolumn{13}{|l|}{$\begin{array}{l}\text { Ventilation/3 (bath/ } \\
\text { cooker/dryer) }\end{array}$} \\
\hline No mechanical ventilation & 202 & Ref & 104 & Ref & 10 & Ref & 149 & Ref & 91 & Ref & 90 & Ref \\
\hline $1 / 3$ ventilation & 161 & $\begin{array}{l}-0.1(-0.4 \\
0.2)\end{array}$ & 125 & $\begin{array}{l}-0.5(-1.4 \\
0.3)\end{array}$ & 126 & $\begin{array}{l}-0.2(-1.4 \\
1.0)\end{array}$ & 105 & $\begin{array}{l}0.4(-0.4, \\
1.3)\end{array}$ & 107 & $\begin{array}{l}-0.3(-0.8 \\
0.3)\end{array}$ & 106 & $\begin{array}{l}0.0(-0.8 \\
0.9)\end{array}$ \\
\hline $2 / 3$ ventilation & 96 & $\begin{array}{l}0.0(-0.4 \\
0.4)\end{array}$ & 115 & $\begin{array}{l}0.1(-0.8, \\
1.0)\end{array}$ & 150 & $\begin{array}{l}0.3(-0.9, \\
1.4)\end{array}$ & 53 & $\begin{array}{l}0.3(-0.7 \\
1.4)\end{array}$ & 73 & $\begin{array}{l}0.1(-0.5, \\
0.7)\end{array}$ & 95 & $\begin{array}{l}0.2(-0.7 \\
1.1)\end{array}$ \\
\hline $3 / 3$ ventilation & 23 & $\begin{array}{l}0.4(-0.2, \\
1.1)\end{array}$ & 29 & $\begin{array}{l}-0.4(-1.8 \\
1.0)\end{array}$ & 23 & $\begin{array}{l}0.5(-1.7 \\
2.6)\end{array}$ & 19 & $\begin{array}{l}1.2(-0.4, \\
2.8)\end{array}$ & 14 & $\begin{array}{l}0.1(-1.1 \\
1.2)\end{array}$ & 19 & $\begin{array}{l}0.4(-1.1 \\
2.0)\end{array}$ \\
\hline \multicolumn{13}{|l|}{$\begin{array}{l}\text { Insulation/3 (roof/ } \\
\text { wall/underfloor or slab) }\end{array}$} \\
\hline $3 / 3$ insulation & 174 & Ref & 21 & Ref & 94 & Ref & 74 & Ref & 48 & Ref & 38 & Ref \\
\hline $2 / 3$ insulation & 133 & $\underset{* * *}{0.8}(0.5,1.2)$ & 293 & $\begin{array}{l}0.0 \\
(-1.4,1.4)\end{array}$ & 221 & $\begin{array}{l}-1.1(-2.4 \\
0.2)^{\wedge}\end{array}$ & 91 & $\begin{array}{l}-0.6(-1.6 \\
0.4)\end{array}$ & 123 & $\begin{array}{l}-0.7(-1.3 \\
-0.0)^{*}\end{array}$ & 202 & $\begin{array}{l}-1.2(-2.4 \\
-0.1)^{*}\end{array}$ \\
\hline $1 / 3$ insulation & 150 & $\underset{* * *}{0.9}(0.5,1.3)$ & 59 & $\begin{array}{l}0.3 \\
(-1.3,1.9)\end{array}$ & 77 & $\begin{array}{l}-0.8(-2.4 \\
0.8)\end{array}$ & 137 & $\begin{array}{l}-0.6(-1.5 \\
0.4)\end{array}$ & 109 & $\begin{array}{l}-0.5(-1.2 \\
0.2)\end{array}$ & 65 & $\begin{array}{l}-0.8(-2.2 \\
0.5)\end{array}$ \\
\hline No insulation & 25 & $\begin{array}{l}0.6(-0.2 \\
1.3)\end{array}$ & & & 8 & $\begin{array}{l}-1.4(-4.8 \\
2.0)\end{array}$ & 24 & $\begin{array}{l}-0.5(-2.0 \\
1.1)\end{array}$ & 5 & $\begin{array}{l}1.0(-0.8 \\
2.8)\end{array}$ & 5 & $\begin{array}{l}0.8(-2.1 \\
3.6)\end{array}$ \\
\hline $\begin{array}{l}\text { Trend } \\
\text { Subfloor/3 (ventilation/ } \\
\text { ponding\&leaks/ } \\
\quad \text { groundcover) }\end{array}$ & & $\mathrm{P}<0.01$ & & $\mathrm{P}<0.05$ & & NS & & NS & & NS & & NS \\
\hline No subfloor defects & 155 & Ref & 128 & Ref & 145 & Ref & 21 & Ref & 25 & Ref & 32 & Ref \\
\hline $1 / 3$ subfloor defects & 159 & $\begin{array}{l}0.0(-0.3 \\
0.3)\end{array}$ & 120 & $\begin{array}{l}0.0(-0.9 \text {, } \\
0.9)\end{array}$ & 109 & $\begin{array}{l}-1.2(-0.0 \\
2.4)^{\wedge}\end{array}$ & 164 & $\begin{array}{l}0.4 \\
(-0.9,1.7)\end{array}$ & 203 & $0.7(-0.1,1.5)$ & 107 & $\begin{array}{l}0.9 \\
(-0.3,2.1)\end{array}$ \\
\hline $2 / 3$ subfloor defects & 146 & $\begin{array}{l}0.3(-0.2, \\
0.7)\end{array}$ & 103 & $\begin{array}{l}0.2(-0.8, \\
1.1)\end{array}$ & 127 & $\begin{array}{l}-0.3(-1.5 \\
0.9)\end{array}$ & 125 & ${ }_{* *} .9(0.5,3.2)$ & 57 & ${ }_{* *} .2(0.3,2.2)$ & 148 & $\operatorname{lik}_{* *}(0.5,2.8)$ \\
\hline $3 / 3$ subfloor defects & 22 & $\begin{array}{l}-0.0(-0.8 \\
0.7)\end{array}$ & 22 & $\begin{array}{l}0.1(-1.5, \\
1.7)\end{array}$ & 19 & $\begin{array}{l}1.1(-1.2, \\
3.3)\end{array}$ & 16 & $\begin{array}{l}1.1 \\
(-0.9,3.0)\end{array}$ & & & 23 & $\begin{array}{l}3.7(2.0,5.4) \\
* * *\end{array}$ \\
\hline \multicolumn{13}{|l|}{$\begin{array}{l}\text { BEC/5 (Poorer condition } \\
\text { of; roof cladding/wall } \\
\text { cladding/windows/ } \\
\text { exterior paint/ } \\
\text { spouting and } \\
\text { guttering) }\end{array}$} \\
\hline $0-1$ condition deficit & 284 & Ref & 118 & Ref & 192 & Ref & 169 & Ref & 72 & Ref & 169 & Ref \\
\hline 2-3 factor deficit & 147 & $\begin{array}{l}-0.0(-0.4 \\
0.3)\end{array}$ & 123 & $\begin{array}{l}0.1(-0.8, \\
0.9)\end{array}$ & 109 & $\underset{* *}{1.6}(0.4,2.8)$ & 115 & $\begin{array}{l}-0.0(-0.8 \\
0.8)\end{array}$ & 110 & $0.5(-0.1,1.1)$ & 115 & $\begin{array}{l}0.9(-0.0 \\
1.8)^{*}\end{array}$ \\
\hline 4-5 factor deficit & 51 & $\begin{array}{l}-0.5(-1.0 \\
0.02)^{\wedge}\end{array}$ & 70 & $\begin{array}{l}0.6(-0.4, \\
1.7)\end{array}$ & 99 & $\begin{array}{l}0.5(-0.9 \text {, } \\
2.0)\end{array}$ & 42 & $\underset{* * *}{1.8}(0.7,2.9)$ & 58 & $\begin{array}{l}0.3(-0.4, \\
1.0)\end{array}$ & 42 & $\underset{* * *}{1.5}(0.5,2.5)$ \\
\hline missing & & & 62 & $\begin{array}{l}0.1(-0.9 \\
1.1)\end{array}$ & & & & & 45 & $\begin{array}{l}0.5(-0.2, \\
1.2)\end{array}$ & & \\
\hline $\begin{array}{l}\text { Trend } \\
\text { OCR }\end{array}$ & & NS & & NS & & NS & & $\mathrm{P}=0.1$ & & NS & & $\mathrm{P}<0.01$ \\
\hline Excellent & 240 & $R e f$ & 98 & $R e f$ & 188 & Ref & 134 & Ref & 69 & Ref & 114 & Ref \\
\hline Moderate & 165 & $\begin{array}{l}-0.2(-0.5 \\
0.2)\end{array}$ & 94 & $\begin{array}{l}0.6 \\
(-0.3,1.5)\end{array}$ & 160 & $\begin{array}{l}0.5(-0.7 \\
1.7)\end{array}$ & 128 & $\begin{array}{l}0.1 \\
(-0.8,0.9)\end{array}$ & 71 & $\begin{array}{l}0.1 \\
(-0.6,0.8)\end{array}$ & 139 & $0.8(-0.1,1.6)$ \\
\hline Poor & 77 & $\begin{array}{l}0.2(-0.2, \\
0.7)\end{array}$ & 87 & $\begin{array}{l}1.3(0.2,2.3) \\
*\end{array}$ & 68 & $\begin{array}{l}1.0(-1.6, \\
1.8)\end{array}$ & 64 & $\begin{array}{l}-0.2 \\
(-1.30 .8)\end{array}$ & 76 & $\begin{array}{l}0.5 \\
(-0.3,1.2)\end{array}$ & 67 & $\begin{array}{l}1.3(0.3,2.4) \\
*\end{array}$ \\
\hline missing & & & 94 & $\begin{array}{l}0.1 \\
(-0.9,1.1)\end{array}$ & & & & & 69 & $\begin{array}{l}-0.8(-1.6,- \\
0.1)^{*}\end{array}$ & & \\
\hline trend & & NS & & NS & & NS & & NS & & NS & & $\mathrm{P}<0.05$ \\
\hline
\end{tabular}

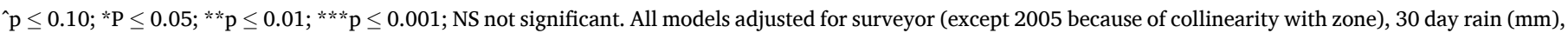
30 day mean high temperature $\left({ }^{\circ} \mathrm{C}\right)$, occupancy $\&$ tenure.

simple visual inspection, and hidden defects, such as cracked grouting and tiles, or loosening around nails and rust underneath joins, which are more likely in older houses, may contribute to this increased moisture in the roof space. We speculate that the association with different roofing materials may be related to differential solar heat adsorption and airtightness properties of tiled/concrete and sheet metal roofs. However, we were not able to assess this in the current study.

The strong association between subfloor defects (insufficient ventilation, ponding or leaks and lack of ground moisture barrier) and increased floor joist moisture content was expected, due to the proximity of the moisture sources (and modulating parameters) to where the measurements were taken. These three subfloor factors have previously been identified as related to high indoor dampness [50,51]; however, to our knowledge, no other studies have assessed associations between house characteristics and objectively measured moisture in the subfloor framing, while also adjusting for other known contributors to indoor 
dampness. Our results show the apparent additive nature of these three factors, as reflected in the significant trend of increasing frequency of subfloor defects with increasing floor joist moisture. This is particularly apparent in the 2015 survey, the first of our three surveys to include more than a handful of houses with a ground moisture barrier present.

An increase in the number of building envelope defects in the aggregated BEC was associated with increasing moisture content in the floor joist. Two mechanisms may explain this. Firstly, water infiltrating the envelope via defects in the cladding may collect at the base of the wall framing and sub floor framing due to gravity, where it can be transported through flooring materials to floor joists via capillary action. Secondly, water accumulating around the base of the house due to defects in the storm water system may create a damp microclimate around the subfloor space and structure. Unlike the BEC, the inspectors' OCR did not show consistent associations with floor or roof joist moisture content, which suggests that a general indicator such as OCR may not be sufficiently specific as a proxy of moisture. To our knowledge, no other studies have assessed associations between house condition or repair and measured moisture, either in framing or indoors, although one study demonstrated a link between older houses (a proxy for poor repair) and increased relative humidity indoors [27].

Increased mechanical ventilation, which was strongly associated with reduced indoor dampness here, as well as with both mould and musty odour in our earlier study [24], was not clearly associated with measured moisture content in the floor or roof joists. As wall cavity and framing moisture is generally considered to be strongly affected by the infiltration of moisture produced indoors by occupants [42,52], we had expected an inverse association between insulation and ventilation and floor and ceiling joist moisture content. However, this was not the case. This suggests that floor and ceiling joist moisture content may be less affected by moisture from the indoor environment; instead it may be more affected by the impact of moisture originating from outdoors (see section 4.1), although this could not be confirmed in this study.

The significant trend with fewer aggregated insulation factors and higher ceiling joist moisture content in 2005 and 2010 (Table 7) is similar to what we found for subjectively measured indoor dampness (Table 4), and visible mould and mouldy odour, as reported earlier [24]. The reasons for this may be the same as described for subjectively measured moisture (see above); however, the fact that ceiling insulation was not independently associated with ceiling joist moisture in the non-aggregated analysis, suggests that this result may reflect confounding with some other related construction factor. No clear association between insulation and floor joist moisture was found.

This study also found that that poorer roof condition was associated with increased floor joist moisture. The reasons for this are unclear.

A further analysis was conducted looking specifically at recorded insulation defects, including gaps, settling, poor fit and other unspecified damage. Presence of these defects was summed (with no insulation present coded as the highest category) and the index tested against dampness and moisture measurements. The relationship of this index with dampness and moisture measurements was inconsistent across surveys (data not shown).

\subsection{Limitations}

An important weakness of the study was the lack of data on behaviour of the occupants, which may confound associations between house characteristics and indoor dampness. However, occupant behaviour may not have been a strong confounder as results were reasonably consistent between surveys despite taking place in different seasons (the 2005 survey was conducted almost entirely in summer and the 2010 almost entirely in winter and spring) when occupant behaviours were likely very different. Furthermore, as associations were relatively strong and showed dose-response patterns, it is unlikely to be explained entirely by confounding. Nonetheless, confounding by occupant behaviour cannot be excluded.
Inspector-rated indoor dampness (based on the subjective feeling or sensation of indoor humidity or dampness) in our study was not entirely comparable to similar reported outcomes in the international literature, where it is often based on a visual inspection, including damp stains, patches and sometimes condensation [16,21,22,44,53]. Similarly, our study focussed on a specific style of housing, namely timber-framed houses, and was conducted in a temperate maritime climate, characterised by a narrow range of temperatures and high humidity year-round. This is different from many other studies, somewhat limiting the comparability of our results. Nonetheless, despite these differences, many of the associations between household characteristics and dampness observed in our study were similar to those reported in the literature. Additionally, although moisture measurement instruments were calibrated at the start of the study, they were not recalibrated, so we cannot ascertain that instrument drift did not occur, nor to what extent such drift may have affected our results.

Our results, particularly in unaggregated analyses, were sometimes inconsistent across the three samples. This may be due to the relatively small number of houses with particular characteristics in some surveys (e.g. presence of a ground cover vapour barrier in the first two surveys) resulting in reduced study power for some analyses. Also, a lack of rental and poorly maintained houses in the first (2005) survey may have resulted in some associations not being observed in this survey particularly those related to the condition of the house. Furthermore, climate differences due to sampling at different times of the year has likely impacted on the proportion of homes with dampness, again limiting the statistical power for some surveys. Finally, not being able to control the analyses for human behaviour (as discussed above), may have differentially affected the results for each of the surveys.

\section{Conclusions}

Our study showed that subfloor and building envelope defects were associated with both subjectively assessed indoor dampness and objectively measured floor joist moisture content, whilst insulation, ventilation, occupancy and tenure were associated only with subjectively assessed indoor dampness. These results provide important new insights that may facilitate the development of more effective interventions to reduce indoor dampness. However, significant knowledge gaps remain in understanding of how human behaviour mediates the relationship between house characteristics and indoor dampness and building moisture. Future work taking into account human behaviour (e.g. use of heaters and ventilation practices) and across a wide range of climatic zones is needed to ensure that interventions are optimally effective for all homes and living conditions.

\section{Declaration of competing interest}

The authors declare that they have no known competing financial interests or personal relationships that could have appeared to influence the work reported in this paper.

\section{Acknowledgements}

We would like to thank the researchers, inspectors and participating households who were involved in the three Building Research Association of New Zealand (BRANZ) House Condition Surveys. We are also grateful to the Centre for Research, Evaluation and Social Assessment (CRESA) and the National Institute of Water and Atmospheric Research (NIWA) for provision of additional data. The House Condition Surveys, and a PhD scholarship were funded from the Building Research Levy. House Condition Surveys were further supported by funding from CRESA, the Ministry for Business Innovation and Employment (MBIE) and the Energy Efficiency and Conservation Authority (EECA). 


\section{Appendix A. Supplementary data}

Supplementary data to this article can be found online at https://doi. org/10.1016/j.buildenv.2021.108508.

\section{References}

[1] M.J. Mendell, K. Kumagai, Observation-based metrics for residential dampness and mold with dose-response relationships to health: a review, Indoor Air 27 (3) (2017) 506-517.

[2] C.G. Bornehag, G. Blomquist, F. Gyntelberg, B. Järvholm, P. Malmberg, L. Nordvall, A. Nielsen, G. Pershagen, J. sundell, Dampness in buildings and health, Indoor Air 11 (2) (2001) 72-86.

[3] M.J. Mendell, A.G. Mirer, K. Cheung, M. Tong, J. Douwes, Respiratory and allergic health effects of dampness, mold, and dampness-related agents: a review of the epidemiologic evidence, Environ. Health Perspect. 119 (6) (2011) 748-756.

[4] C.G. Bornehag, J. Sundell, S. Bonini, A. Custovic, P. Malmberg, S. Skerfving, T. Sigsgaard, A. Verhoeff, Dampness in buildings as a risk factor for health effects, EUROEXPO: a multidisciplinary review of the literature (1998-2000) on dampness and mite exposure in buildings and health effects, Indoor Air 14 (4) (2004) 243-257.

[5] P.F. Rosenbaum, J.A. Crawford, A. Hunt, S.J. Vesper, J.L. Abraham, Environmental relative moldiness index and associations with home characteristics and infant wheeze, J. Occup. Environ. Hyg. 12 (1) (2015) 29-36.

[6] T. Reponen, L. Levin, S. Zheng, P. Ryan, S.A. Grinshpun, G. LeMasters, Family and home characteristics correlate with mold in homes, Environ. Res. 124 (2013) 67-70.

[7] M.J. Mendell, R.I. Adams, The challenge for microbial measurements in buildings, Indoor Air 29 (4) (2019) 523-526.

[8] S. Vesper, R. McKinstry, R. Haughland, L. Wymer, K. Bradham, P. Ashley, D. Cox, G. Dewalt, W. Friedman, Development of an environmental relative moldiness index for US homes, J. Occup. Environ. Med. 49 (8) (2007) 829-833.

[9] C. Shorter, J. Crane, N. Pierse, P. Barnes, J. Kang, K. Wickens, J. Douwes, T. Stanley, M. Taubel, A. Hyvarinen, P. Howden-Chapman, amp; the Wellington Region General Practitioner Research Network, Indoor visible mold and mold odor are associated with new-onset childhood wheeze in a dose-dependent manner, Indoor Air 28 (1) (2018) 6-15, 2018.

[10] G. Smedje, J. Wang, D. Norback, H. Nilsson, K. Engvall, SBS symptoms in relation to dampness and ventilation in inspected single-family houses in Sweden, Int. Arch. Occup. Environ. Health 90 (7) (2017) 703-711.

[11] C.J. Martin, S.D. Platt, S.M. Hunt, Housing conditions and ill health, Br. Med. J. 294 (6580) (1987) 1125-1127.

[12] K. Wickens, R. Seibers, I. Ellis, S. Lewis, G. Sawyer, S. Tohill, L. Stone, R. Kent, J. Kennedy, T. Slater, A. Crothall, H. Trethowen, N. Pearce, P. Fitzharris, J. Crane Determinants of house dust mite allergen, in homes in Wellington, New Zealand, Clin. Exp. Allergy 27 (1997) 1077-1085.

[13] M. Kipelnainen, E.O. Terho, H. Helenius, M. Koskenvuo, Home dampness, current allergic diseases, and respiratory infections among young adults, Thorax 56 (2001) $462-467$.

[14] A. Bradman, J. Chevrier, I. Tager, M. Lipsett, J. Sedgwick, J. Macher, A.B. Vargas, E.B. Cabrera, J.M. Camacho, R. Weldon, K. Kogut, N.P. Jewell, B. Eskenazi, Association of housing disrepair indicators with cockroach and rodent infestations in a cohort of pregnant Latina women and their children, Environ. Health Perspect. 113 (12) (2005) 1795-1801.

[15] L. Hagerhed-Engman, C.G. Bornehag, J. Sundell, Building characteristics associated with moisture related problems in 8,918 Swedish dwellings, Int. J. Environ. Health Res. 19 (4) (2009) 251-265.

[16] M. Lanthier-Veilleux, M. Genereux, G. Baron, Prevalence of residential dampness and mold exposure in a University student Population, Int. J. Environ. Res. Publ. Health 13 (2) (2016) 194.

[17] C.N. Packer, S. Stewart-Brown, S.E. Fowler, Damp housing and adult health: results from a lifestyle study in Worcester, England, J. Epidemiol. Commun. Health 48 (1994) 555-559.

[18] R.E. Dales, R. Burnett, H. Zwanenburg, Adverse health effects among adults exposed to home dampness and molds, Am. Rev. Respir. Dis. 143 (1991) 505-509.

[19] P. Howden-Chapman, A. Matheson, J. Crane, H. Viggers, M. Cunningham, T. Blakely, C. Cunningham, A. Woodwards, K. Saville-Smith, D. O’Dea, M. Kennedy, M. Baker, N. Waipara, R. Chapman, G. Davie, Effect of insulating existing houses on health inequality: cluster randomised study in the community, BMJ 334 (7591) (2007) 460.

[20] U. Haverinen-Shaughnessy, J. Pekkanen, A. Hyvarinen, A. Nevalainen, T. Putus, M. Korppi, D. Moschandreas, Children's homes-determinants of moisture damage and asthma in Finnish residences, Indoor Air 16 (3) (2006) 248-255.

[21] B. Brunekreef, D. Dockery, F. Speizer, J. Ware, J. Spengler, B.( Ferris, Home dampness and respiratory morbidity in children, Am. Rev. Respir. Dis. 140 (1989) 1363-1367.

[22] J. Spengler, L. Neas, S. Nakai, D. Dockery, F. Speizer, J. Ware, M. Raizenne, Respiratory symptoms and housing characteristics, Indoor Air 4 (1994) 72-84.

[23] S.D. Platt, C.J. Martin, S.M. Hunt, C.W. Lewis, Damp housing, mould growth and symptomatic Health State, Br. Med. J. 298 (6689) (1989) 1673-1678.
[24] P. Taptiklis, R.A. Phipps, M.J. Jones, J. Douwes, House characteristics and condition as determinants of visible mould and musty odour: results from three New Zealand House Condition Surveys, in 20052010 and 2015, Indoor Air 31 (3) (2021) 818-831.

[25] D.P. Strachan, C.H. Sanders, Damp housing and childhood asthma, J. Epidemiol. Commun. Health 43 (1989) 7-14.

[26] T. Psomas, D. Teli, S. Langer, P. Wahlgren, P. Wargoki, Indoor humidity of dwellings and association with building characteristics, behaviors and health in a northern climate, Build. Environ. 198 (2021).

[27] T. Oreszczyn, I. Ridley, S.H. Hong, P. Wilkinson, Mould and winter indoor relative humidity in low income households in England, Indoor Built Environ. 15 (2) (2006) 125-135.

[28] A.G. Fakunle, G.R. Ana, M.T. Olaiya, Housing quality and risk of acute respiratory infections among hospitalized children under five in Ibadan, Nigeria, Indoor Built Environ. 25 (8) (2016) 1259-1266, 2016.

[29] E. Ceylan, A. Ozkutuk, G. Ergor, M. Yucesoy, O. Itil, S. Caymaz, A. Cimrin, Fungi and indoor conditions in asthma patients, J. Asthma 43 (10) (2006) 789-794.

[30] J. Wang, K. Engvall, G. Smedje, D. Norback, Rhinitis, asthma and respiratory infections among adults in relation to the home environment in multi-family buildings in Sweden, PLoS One 9 (8) (2014) e105125.

[31] R.A. Sharpe, N. Bearman, C.R. Thornton, K. Husk, N.J. Osborne, Indoor fungal diversity and asthma: a meta-analysis and systematic review of risk factors, J. Allergy Clin. Immunol. 135 (1) (2015) 110-122.

[32] R.A. Sharpe, C.R. Thornton, V. Nikolaou, N.J. Osborne, Fuel poverty increases risk of mould contamination, regardless of adult risk perception \& ventilation in social housing properties, Environ. Int. 79 (2015) 115-129.

[33] World Health Organisation, Guidelines for Indoor Air Quality: Dampness and Mould, 2009.

[34] V. White, M. Jones, Warm, Dry, Healthy? Insights from the 2015 House Condition Survey on Insulation, Ventilation, Heating and Mould in New Zealand Houses, 2017. SR372. BRANZ: Porirua, New Zealand.

[35] N.R. Buckett, N. Marston, K. Saville-Smith, J.H. Jowett, M. Jones, Preliminary BRANZ 2010 House Condition Survey Report - Second Edition. SR240, BRANZ, Porirua, 2011.

[36] S.J. Clark, M. Jones, I.C. Page, New Zealand 2005 House Condition Survey. SR142, BRANZ: Porirua, New Zealand, 2005.

[37] V. White, M. Jones, V. Cowan, S. Chun, BRANZ 2015 house condition survey: Comparison of house condition by tenure. SR370, BRANZ: Porirua, New Zealand, 2017.

[38] B.R.A.N.Z. Weathertightness, Resource On the Background and Remediation of Weathertightness Problems, 2021. Webpage available from: https://www.branz. co.nz/weathertightness/. (Accessed 23 September 2021). accessed.

[39] M.J. Mendell, J.M. Macher, K. Kumagai, Measured moisture in buildings and adverse health effects: a review, Indoor Air 28 (4) (2018) 488-499.

[40] National Institute for Water and Air (NIWA) New Zealand, Cliflo. Accessed 20 February 2019. http://cliflo.niwa.co.nz.

[41] P. Howden-Chapman, K. Saville-Smith, J. Crane, N. Wilson, Risk factors for mold in housing: a national survey, Indoor Air 15 (6) (2005) 469-476.

[42] W.B. Rose, Water in Buildings: an Architect's Guide to Moisture and Mold. 2005, John Wiley \& sons, U.S.A, 2005.

[43] M.D. Keall, J. Crane, M.G. Baker, K. wickens, P. Howden-Chapman, M. Cunningham, A measure for quantifying the impact of housing quality on respiratory health: a cross-sectional study, Environ. Health 11 (2012) 33, 2012.

[44] Y. Sun, J. Sundell, On associations between housing characteristics, dampness and asthma and allergies among children in Northeast Texas, Indoor Built Environ. 22 (4) (2013) 678-684.

[45] J.P. Zock, D. Jarvis, C. Luczynska, J. Sunyer, P. Burney, the European Community Respiratory Health Survey, Housing characteristics, reported mold exposure, and asthma in the European Community Respiratory Health Survey, J. Allergy Clin. Immunol. 110 (2) (2002) 285-292.

[46] W. Liu, C. Huang, Y. Hu, Z. Zou, S. Li, J. Sundell, Associations of building characteristics and lifestyle behaviors with home dampness-related exposures in Shanghai dwellings, Build. Environ. 88 (2015) 106-115.

[47] C.M. Kercsmar, D.G. Dearborn, M. Schluchter, L. Xue, H.L. Kirchner, J. Sobolewski, S.J. Greenberg, S.J. Vesper, T. Allan, Reduction in asthma morbidity in children as a result of home remediation aimed at moisture sources, Environ. Health Perspect. 114 (10) (2006) 1574-1580.

[48] S. Rupp, M. Plagmann, I. Cox-Smith, Airtightness of Roof Cavities, SR401 BRANZ: Porirua, New Zealand, 2018.

[49] L. Quaglia, M. Cunningham, Air Flow Rates Field Measurements, SR180 BRANZ, Porirua, New Zealand, 2007.

[50] H.A. Trethowen, A Survey of Subfloor Ground Evaporation Rates, SR180 BRANZ, Porirua, New Zealand, 1988.

[51] W.B. Rose, A. TenWolde, Issues in crawlspace design and construction - a symposium summary, in: American Society of Heating Refrigeration and AirConditioning Engineers. ASHRAE: New Orleans, Louisiana, USA, 1994.

[52] G. Overton, Vapour Control in New Zealand Walls, SR344 BRANZ, Porirua, New Zealand, 2016.

[53] C.G. Bornehag, J. Sundell, L. Hagerhed-Engman, T. Sigsggard, S. Janson, N. Aberg, the DHB study Group, Dampness' at home and its association with airway, nose, and skin symptoms among 10,851 preschool children in Sweden: a cross-sectional study, Indoor Air 15 (2005) 48-55. 